\title{
Dimensões históricas do fenômeno religioso
}

\section{A construção da Ordem Carmelita: desenvolvimento e práticas espirituais}

The construction of the Carmelite Order: development and spiritual practices

\author{
Nívea Maria Leite Mendonça ${ }^{1}$ \\ niveajf@hotmail.com
}

Resumo: Durante os anos finais da Idade Média,as Ordens Mendicantes ganharam mais destaque dentro do catolicismo ocidental e,com sua expansão, houve uma maior participação de leigos em assuntos até então exclusivos do clero. Observaremos o movimento eremítico iniciado pelo Profeta Elias, figura essencial dentro da espiritualidade Carmelita que também foi um modelo de vivência espiritual no mundo cristão.Devido à sua experiência com o sagrado, ele é considerado o "pai fundador" da Ordem do Carmo. Também analisaremos a instalação da ordem carmelita na América portuguesa, com destaque para a Capitania de Minas Gerais e suas peculiaridades no que diz respeito à Ordem Terceira.

Palavras-chave: Ordem Terceira do Carmo;eremita;leigos;Minas Gerais.

\begin{abstract}
During the final years of the Middle Ages, the Mendicant Orders got a more prominent role in the western Catholicism, and, with their expansion, there was a bigger involvement of laypeople in matters that up to that point were exclusive to the clergy.We will see the eremitic movement initiated by the prophet Elijah, a central figure among the Carmelites' spirituality who was also a model for spiritual communion in the Christian world. Due to his experience with the divine, he is considered the "founding father" of the carmelite order. We will also analyze the establishment of the Carmelite Order in the Portuguese America, with a focus on the Captaincy of Minas Gerais and its peculiarities regarding the Third Order.
\end{abstract}

Keywords: Third Order of Carmel, hermit, laypeople, Minas Gerais.

\section{Introdução ${ }^{2}$}

No Catolicismo difundido dentro da cristandade, a Ordem do Carmo, desde seus primórdios, sempre teve um importante protagonismo, a começar com seu próprio estabelecimento na Europa, em finais da Idade Média.Seu principal impacto foi o advento das Ordens Mendicantes e, consecutivamente, o aumento da participação de leigos em assuntos até então exclusivos do clero.Averiguaremos,neste trabalho, a instalação da ordem carmelita

\footnotetext{
${ }^{1}$ Mestra em História pela UFJF e doutoranda em Históriapela Universidade Federal Fluminense(UFF).

${ }^{2}$ Este artigo é uma versão de parte do primeiro capítulo da minha dissertação de Mestrado: "Entre a hierarquia e a devoção: a dinâmica interna e o relacionamento dos terceiros com a Ordem Carmelita em Minas Gerais. (17471808) ", defendida em agosto de 2015.
} 
na Península Ibérica, assim como nas colônias da América portuguesa, com destaque para a capitania de Minas Gerais e suas peculiaridades.

\section{O surgimento da espiritualidade leiga}

A Ordem Terceira ${ }^{3}$ do Carmo foi criada na Europa,no final do período medieval, tendo como principal embasamento os movimentos iniciados pelas Ordens Mendicantes. Para acompanhar e entender essas raízes faz-se necessário, primeiramente, retornar um pouco no tempo, a fim de verificar como as fraternidades laicas ganharam espaço dentro da Igreja Católica.

Durante a Idade Média, as ordens religiosas ${ }^{4}$ se multiplicaram na Europa ocidental, adquirindo uma forte presença espiritual e devocional(Vauchez, 1995). As novas ordens apontavam que a vida nos claustros erasuperior "a tudo o que a terra oferecia de grande e de bom, e isso, porque constituía um estado privilegiado, permitindo o regresso da criatura ao seu Criador, por meio de um serviço fiel (...)" (Vauchez, 1995, p.46). Era a esse estado privilegiado, dentro dos claustros, que muitos fiéis leigos gostariam de ter acesso, pois no mosteiro o sagrado se manifestaria, uma vez que a vida em clausura era vista como uma antecipação do paraíso, lugar onde se praticava a observância das normas religiosas(Vauchez, 1995).Portanto, a vida monástica afastaria o indivíduo da sedução do pecado ${ }^{5}$,sendo, por isso, uma via de salvação(Vauchez, 1995).

A reforma gregoriana (século XI) alargou a distância entreo clero e os leigos (Vauchez,1995) ${ }^{6}$, de modo que o poder sacerdotal foi mais exaltado. No entanto, os leigos não

\footnotetext{
${ }^{3}$ De acordo com o Dicionário Histórico das Minas Gerais, entendia-se como Ordem Terceira "as associações religiosas de leigos que mantinham atividades de incentivo ao culto e à devoção católica, além de oferecer assistência social aos seus irmãos professos (...). Os irmãos terceiros subordinavam-se à regra de sua ordem originária, excluindo, porém, os votos de castidade e clausura (...). "'Ver mais em ROMEIRO, Adriana \& BOTELHO, Angela Vianna. Dicionário Histórico das Minas Gerais- Período Colonial. 3. Ed. Rev. e ampl.Belo Horizonte: Editora Autêntica, 2013, p.296-297. Além disso, de acordo com Balbino Bayón,“A Ordem Terceira Secular do Carmo é uma associação de fiéis que vivem no mundo e que sob a obediência da ordem carmelita e segundo seu espírito, se esforçam por alcançar a perfeição cristã pela observância da regra terceira. O fim principal, portanto, é uma vida mais perfeita, segundo o ideal carmelita: união intima com Deus pelo espírito da oração - uma terníssima devoção à Virgem Puríssima do Carmo - e assim promover, no ambiente em que vivem, o bem da Igreja e a Salvação das almas". (Bayón, 2001, p.487)

${ }^{4}$ Entre as Ordens Religiosas que despontaram no período medieval destacamos: beneditinos, agostinianos eas ordens franciscanas:a de São Domingos e a dos carmelitas.

${ }^{5}$ De acordo com André Vauchez, o monge "era antes de tudo um penitente que entrara na vida religiosa para chorar os seus pecados e para se colocar sob direção espiritual do abade" (Vauchez,1995, p.106).

${ }^{6} \mathrm{De}$ acordo com o autor, os resultados da reforma gregoriana foram contraditórios, já que, por um lado, a reforma diminuiria os espaços de atuação dos leigos; por outro, o próprio papa Gregório VII apelaria “(...) várias vezes aos leigos, sobretudo a príncipes e cavaleiros, para que castigassem os prelados simoníacos e os padres em concubinagem, mesmo pela força se necessário”.Ver também em Le Goff, 2007, p.27-29.
} 
ficaram à margem dos assuntos da religião: encontraram em movimentos, como as Cruzadas, os meios para adquirir um nível espiritual mais elevado, até então exclusivo do clero, pois "com as Cruzadas revela-se pela primeira vez no Ocidente a existência de uma espiritualidade popular, que surge repentinamente como um conjunto coerente" (Vauchez,1995, p.106).Todavia, o principal objetivo designado pelo papa Urbano IIaos cruzados era a libertação do túmulo de Cristo, e, como recompensa, prometia a eles indulgências plenárias (Vauchez,1995).Mas, aos olhos dos cavaleiros, a participação em uma Cruzada refletia numa forma de espiritualidade penitencial, que apagaria os pecados cometidos, através dessas indulgências.

Diante das incertezas e oscilações motivadas pelas grandes transformações, nos anos finais da Idade Média, com o renascimento das cidades e o surgimento da burguesia, o homem medieval foi levado a se organizar em grupos que compartilhavam elementos muito próximos entre si, sejam eles caritativos, pios ou o fato de desempenharem a mesma atividade profissional (Borges, 2005);o essencial nesses grupos era a prática da solidariedade e da sociabilidade,e ficaram caracterizados, principalmente, pelas confrarias (Agulhon,1968). Em Portugal, não se sabe ao certo quando surgiram as confrarias, mas estudos mostram que, no século XII, haveria indícios do aparecimento delas (Borges, 2005). O intuito das associações era a prestação de assistência para seus afiliados,o que garantiu o grande sucesso desse movimento nos anos finais da Idade Média(Vauchez, 1995).O advento confrarial ${ }^{7}$ agregava homens e mulheres, já que, naquele período, o território europeu passava por grande instabilidade, provocada pelas guerras, pestes e altas taxas de mortalidade.

A participação de leigosfoi, portanto, inovadora do século XII em diante, principalmente na Europa Católica, uma vez que estes tiveram um despertar de suas consciências religiosas e espirituais. Mas, como lembra André Vauchez(1995, p.58),a "adesão dos leigos às instituições e aos valores do monarquismo não é, todavia, um simples fenômeno de mimetismo ou de osmose, antes traduz o despertar da consciência religiosa em meios que até então só havia conhecido um simples conformismo". Com a renovação da espiritualidade, os leigos conquistaram espaços de atuação nos assuntos até então exclusivos do clero. Logo:

No fim da Idade Média se firmou o modelo de confraria de leigos que se espalharia pela Época Moderna: uma fraternidade leiga que congregava fiéis em torno de um ou de vários santos patronos (...). Estas confrarias se ligavam a uma igreja, paroquial ou conventual (...). Ao constituir uma rede de integração para seus membros ela se

${ }^{7}$ Em Portugal, muitas confrarias que se desenvolveram eram destinadas a obras piedosas, construindo e administrando as albergarias e hospícios destinados a abrigar os viajantes pobres e peregrinos e os hospitais destinados a assistência aos enfermos. Ver mais em Borges 2005, p.45. 
revestiu de um papel essencial numa dinâmica como aquela que se firmou no Ocidente nos séculos XII e XIII(...) (Evangelista, 2010. p.43).

Muitos leigos, através desse despertar religioso, se lançaram à vida de caráter eremítico $^{8}$, através da qual puderam se "entregar a um asceticismo desenfreado" (Vauchez, 1995,p.61), já que não conseguiriam se tornar monges. Os leigos encontraram como fonte de vida o seguimento dos passos de Cristo, quer"através das Cruzadas ou das peregrinações aos 'lugares santos', ou ainda através da atividade caritativa e da penitência"(Evangelista, 2010, p.44). Embasados pelo ideal eremítico desse tempo, os indivíduos passaram à condição de penitentes, com a aquisição de um vestuário miserável e de uma alimentação que se restringia ao mínimo, isto é, a vegetais que achavam pelo caminho(Vauchez, 1995).

Nesse sentido, os eremitas atraíram muitos seguidores -discípulos - e esses, geralmente, fundavam uma comunidade religiosa, próxima de um lugar de culto(Vauchez, 1995), como as ermidas.Acrescenta-se a isso, o fato de a pobreza, nesse período, ser vista como uma virtude,e, com isso,"o pobre passou gradativamente a adquirir o estatuto de semelhante a Cristo, pois ajudar o pobre significava ajudar a Cristo" (Borges, 2005, p.48).Nessa perspectiva, com o ideal de vida penitencial e de pobreza, surgia, no século XIII, a ordem franciscana, através da ação de Francisco de Assis, que buscou uma comunhão entre o objetivo apostólico e a experiência ascética.

\section{As Ordens Mendicantes e a herança franciscana}

A ordem fundada por Francisco de Assis - a dos irmãos menores ${ }^{9}$ - absorveu alguns ideais dos movimentos espirituais que surgiram na Europa do século XII. Assim como Francisco de Assis instituiu a ordem dos irmãos menores, Domingos de Gusmão fundou a ordem dos pregadores.Essas duas ordens se caracterizaram, inicialmente, pela pobreza e pela missão penitencial e se expandiram principalmente nos meios urbanos, onde podiam colocar a mensagem evangélica "ao alcance de toda a população, como os mercadores, artífices e estudantes (...)" (Martins, 2009, p.36). Logo, as Ordens Mendicantes se inseriram num

\footnotetext{
8 "Eremita é pessoa que vive espiritualmente no ermo, deserto" e ermitão/ermitoa "é o que cuida de alguma ermida" (Carvalho, 2002). Ver também Vieira, 1983 e Borges, 2011.Para André Vauchez, o eremitismo, a partir dos séculos XI e XII, transformou-se num grande fenômeno, que surgia como alternativa à vida monástica (Vauchez, 1995, p.89).

9 Irmãos menores é o nome do movimento fundado por Francisco de Assis, em 1209, logo após o reconhecimento do Pontífice Inocêncio III. Os irmãos menores levavam uma vida de profunda devoção a Cristo, venerado pelo sofrimento que sofrera na Cruz.Tinham como diretriz seguir o exemplo de Cristo e dos Apóstolos, que se afastaram de todas as riquezas mundanas - bens pessoais e intelectuais. Francisco abominava o dinheiro, causador da discórdia e do ódio. Ver mais em Vauchez, 1995.
} 
espaço“intermediário situado entre o clero secular, cujo pequeno número e despreparo limitava em muito o alcance de sua obra pastoral, e as congregações monásticas, contemplativas excessivamente arraigadas à ordem senhorial" (Vauchez, 1995,p.145).As Ordens Mendicantes aos poucospassaram a atrair inúmeros seguidores.

A nova forma de vida introduzida por Francisco de Assis, cuja característica era a prática da pobreza absoluta, propunha a igualdade entre clérigos e leigos(Martins, 2009); afastava-se, assim, dos modelos seguidos pelas ordens monásticas. O movimento de Francisco foi visto, pelos padrões da época, como inovador, senão revolucionário,e:

Igualmente revolucionária para a época a concepção de uma ordem onde clérigos e leigos se encontravam reunidos em pé de igualdade. Francisco, que não tivera formação clerical e só instado pelo Papa recebeu o diaconato, pretendia dar a todos os membros da sua fraternidade os mesmos direitos e os mesmos deveres; o essencial, a seus olhos, era uma prática em comum e sem concessões da pobreza evangélica.(Vauchez, 1995,p.144)

O sucesso das pregações de Francisco de Assis foi tão grande, entre a cristandade, que rapidamente suscitou apreensão, por parte do papado. Sendo assim, havia uma "ameaça de serem considerados heréticos pela Igreja", e isso, "teria levado Francisco a requerer em Roma a legitimação de sua atividade e de seu modo de vida" (Barbosa, 2010). Apesar de toda a inovação introduzida por Francisco de Assis e sua rápida expansão, esse movimento por fim conheceu uma forma de hierarquização, em função de sua institucionalização. Para transformar o movimento em uma ordem religiosa, Francisco precisou adaptar sua "forma de vida" em regra, e para que essa regra tivesse a aprovação papal, precisou aproximá-la do modelo da regra beneditina (Le Goff,2007) ${ }^{10}$. Diante de uma hierarquização de seu movimento, Francisco tentou não se afastarda essência primordial de seu ideal de evangelização. Segundo Jacques Le Goff, a Santa Sé designou um representante de sua confiança - o cardeal Ugolino - para cuidar mais de perto do movimento iniciado por Francisco e, provavelmente, por sugestão desse cardeal, foi criada uma "ordem terceira", que enquadrava a grande multidão de leigos que desejavamentrar na ordem(Le Goff, 2007), naquele momento. Francisco tentou ainda imprimir, dentro do quadro de funções desempenhadas pelos seus seguidores, eleições periódicas dentro de um período geral anual;nelas se encontrava com todos os irmãos, preservando assim o caráter de comunidade do movimento (Evangelista,2010).

\footnotetext{
${ }^{10}$ Após o IV Concilio de Latrão (por volta do ano de 1215),a formação de outras ordens religiosas seria restrita. As decisões postas por este Concílio imprimiam aos candidatos, a limitação de ingressarem em uma das ordens já aprovadas, até aquele momento, pela Santa Sé. Ver mais emBolton, 1983.
} 
O movimento foi tão inovador que tomou grandes proporções, favorecendo o surgimento de outras Ordens Mendicantes, como a dos eremitas de Santo Agostinho e a da Ordem do Carmo. Quanto a esta,os historiadores carmelitas e seus cronistas relacionaram a origem da Ordem do Carmo aos peregrinos da Terra Santa e os cruzados, que se retiraram para o Monte Carmelo e conseguiram do patriarca de Jerusalém que lhes aprovassem uma norma para governarem, em 1209 (Bayón, 2001). Mais tarde, os religiosos, estabelecidos na Europa, por volta de 1245, foram elevados à categoria das Ordens Mendicantes (Martins, 2009). Para nosso estudo, faz-se necessário assinalar os principais traços, enfatizados pela ordem e divulgados entre os seus membros, através das narrativas que integravam a formação dos irmãos terceiros, objeto do presente estudo.

\section{Os primeiros sinais da ordem carmelita}

A ordem carmelita construiu sua tradição, ${ }^{11}$ em torno da figura do profeta Elias ${ }^{12}$ e do seu discípulo Eliseu. As narrativas míticas do cristianismo concediam à figura de Elias, um papel importante para a formação religiosa, já que lhe foi atribuída a profecia da vinda da Virgem Maria ${ }^{13}$, por ter tido uma visão de uma pequena nuvem, na qual o verbo seria, tempos depois, encarnado. Segundo a versão bíblica, Elias escolheu comosucessor seu discípulo Eliseu $^{14}$, responsável por dar continuidade ao movimento, que tão logo se espalhou,por todos os lugares.

Segundo as narrativas de religiosos, os primeiros discípulos do profeta Elias - e posteriormente de seu sucessor, o também profeta Eliseu - se reuniriam em torno da "fonte do profeta Elias", isto é, o lugar - que é mais exatamente uma gruta -onde ele teria ficado no Monte Carmelo ${ }^{15}$, o qual se tornou uma referência para os discípulos, um lugar sagrado por

\footnotetext{
${ }^{11}$ Privilegiaremos o discurso religioso que se pauta na figura mítica - ou lendária - do profeta Elias e seu sucessor Eliseu, por considerá-los personagens importantes dentro da tradição carmelita.

${ }^{12} \mathrm{O}$ profeta Elias é considerado pela Igreja como pai dos profetas. Ele aparece nas narrativas bíblicas como o defensor do monoteísmo diante da idolatria dos deuses pagãos (1Rs, 18,16-35). As ações desse profeta aparecem representadas como próximas às ações de Cristo (Mc 8, 27-30). Segundo tais narrativas,Elias teve sua experiência mística através do encontro com Deus no alto da montanha - mais especificamente, o Monte Horeb, isto é, "Montanha de Deus" (1Rs19, 11-14). Esteve presente na transfiguração de Cristo (Mt 17,1-9/ Mc 9,1-13) e seu nome é citado pelo povo no momento do Calvário, quando pensam que Jesus clama o seu nome na Cruz mas na verdade Jesus disse "Eloi, Eloi, lama sabactâni?", que significa: "Meu Deus, Meu Deus, por que me abondonaste?" (Mc 15,34-36); ou "Eli, Eli, lamásabactâni? ", que tem o mesmo significado (Mt, 27, 45-47).

${ }^{13} 1$ Rs $18,44$.

${ }^{14}$ As imagens dos profetas Elias e Eliseu e de Nossa Senhora, juntamente com o Monte Carmelo, serão importantes para a constituição do brasão e servirão de referência para a criação dos atributos das devoções carmelitas (Campos, 2011).

${ }^{15}$ Monte Carmelo fica situado na região da Palestina, e segundo as passagens bíblicas a região desse monte era de extrema beleza. Ver mais emEvangelista, 2010.
} 
excelência, sendo "por consequência, 'forte' e significativo" (Eliade, 2010, p.25); para seus seguidores, ao se fixarem, adotaram como estilo de vida o eremitismo. O grupo teria se refugiado no monte em busca do silêncio e da união divina ${ }^{16}$. Somente com o isolamento e a contemplação vivenciados por Elias, acreditava-se que seria possível ter contato mais próximo com o divino, como aconteceu com esse profeta ${ }^{17}$. Todavia, para os discípulos do profeta Elias, a concepção religiosa do mundo requeria um desapego do indivíduo, que desejava aproximar-se do sagrado (Callois, 1988); por isso, o total isolamento. E, impulsionados por essa narrativa mítica, antigos cavaleiros que participaram (provavelmente) da terceira Cruzada teriam se instalado no Monte Carmelo(Borges,2011). Contribuiu para esse movimento, a procura do monte por alguns peregrinos da devoti Deo peregrini, que teriam dado início a uma experiência eremítica e ascética (Evangelista, 2010), tendo assim instaurado a devoção na montanha e ganhado inúmeros adeptos. Por volta dos anos de 12061214 Alberto $^{18}$, bispo e patriarca de Jerusalém, teria reunido os eremitas do Monte Carmelo e escrito para eles a Vitae formula(Evangelista, 2010), que mais tarde se tornou a Regra da Ordem Carmelita(Bayón, 2001). Por sua importante participação, Santo Alberto foi considerado um dos fundadores da Ordem.

Contudo, a ordem carmelita só se tornou uma ordem reconhecida, diante das autoridades da Igreja Católica, quando a Vitae formula foi oficialmente aprovada pelo papa Inocêncio IV em $1247^{19}$. Da redação da regra feita por Santo Alberto, à aprovação definitiva, decretada pelo papa Inocêncio IV,decorreram quarenta anos $(1207-1247)^{20}$.

\footnotetext{
161 Rs 19, 38. Para MirceaEliade, a montanha seria o lugar predileto para os homens religiosos, pois estes acreditavam que tais lugares estavam mais próximos do divino e, por isso, se revelavam como o centro do mundo. Segundo esse autor, "numerosas culturas falam-nos dessas montanhas - míticas ou reais - situadas no Centro do Mundo" e "é o que proclama a tradição israelita: a Palestina, sendo a região mais elevada, não foi submersa pelo dilúvio". Vemos que essa região sempre foi considerada pelo "povo de Deus" como um lugar singular para as manifestações do sagrado. Ver mais emEliade, 2010, p.39.

${ }^{17}$ Essa passagem bíblica mostra Javé (Deus) indo ao encontro do profeta Elias no Monte “(...) Então aconteceu um furacão que de tão violento rachava as montanhas e quebrava as rochas diante de Javé. No entanto, Javé não estava no furacão. Depois do furacão houve um terremoto. Javé, porém, não estava no terremoto. Depois do terremoto, apareceu fogo, e Javé não estava no fogo. Depois do fogo, ouviu-se uma brisa suave. Ouvindo-a, Elias cobriu o rosto com o manto, saiu e ficou na entrada da gruta (...)" 1Rs 19, 11-13. Nesse sentido, os eremitas do Monte Carmelo, a exemplo de Elias, queriam ter esse contato com o sagrado, mas para tê-lo era necessário o silêncio para se alcançar a contemplação.

${ }^{18}$ Alberto, patriarca de Jerusalém, conseguiria reunir em comunidade os eremitas do Monte Carmelo,dando-lhes uma Regra que Inocêncio III e muitos outros Papas confirmaram com bulas, aprovando a dita Ordem. Ver mais emBayón, 2001.

${ }^{19} \mathrm{O}$ texto de Alberto foi escrito em 1207 como simples forma de vida. Mas somente em 1247 é que o texto da regra foi oficialmente aprovado como Regra da Ordem do Carmo. Vale ressaltar aqui algumas datas importantes para sua aprovação: em 1207, Alberto escreve a Vitae formula; em 1226 o papa Honório III aprova o texto como regra - pois diz que a Vitae formula escrita por Alberto era anterior ao decreto do Concilio de Lateranense, que estabeleceu a proibição de criação de novas ordens e a elaboração de novas regras; em 1229 o papa Gregório IX reafirma a aprovação dessa Regra, conferindo aos carmelitas uma identidade distinta das grandes ordens; e em 1247 o papa Inocêncio IV aprova definitivamente a regra carmelita e faz algumas alterações no texto da regra de
} 


\section{A ordem carmelita em Portugal}

A Ordem do Carmo é também denominada de Bem-Aventurada Sempre Virgem Maria do Monte Carmelo. Segundo a versão divulgada pela ordem, os primeiros carmelitas, que se estabeleceram em Portugal, foram os capelães dos militares de São João de Jerusalém, de origem da Terra Santa. Esses clérigos se fixaram no convento construído por esses militares, sendo mais tarde, este convento doado aos carmelitas, por volta do ano 1251, em Moura. Já por volta do século XV, ele contava com quarenta e dois religiosos. Foi a partir deste convento, que a Ordem do Carmo se propagou para todo o território português ${ }^{21}$.

Conta ainda os historiadores da ordem e seus cronistas, que por volta da segunda metade do século XV, D. Nuno Álvares Pereira, o contestável, ${ }^{22}$ juntamente com religiosos carmelitas, construíram um convento carmelita em Lisboa ${ }^{23}$. O primeiro documento, oficial enviado por Urbano VI, de 1386, registrava sobre esta fundação, em resposta à vontade de Nuno Álvares Pereira(Bayón,2001). Constava que, após a construção do convento, se formou uma confraria do Carmo, anexa à construção. Embora, existissem grupos de pessoas ávidas, de uma vida espiritual mais perfeita, os carmelitas não detiveram o direito de agregar leigos à ordem antes de 1476 (Bayón, 2001).

Com a "instituição oficial da ordem terceira carmelita, em 1476, pela bula de Sixto IV e através da intervenção do prior geral da congregação do Carmo, Frei João de Soreth (...)" (Evangelista, 2010, p 51), os leigos puderam ser mais atuantes no seio da Igreja e, com efeito, foram beneficiados com toda a garantia de salvação, que até então era reservada ao clero,

\footnotetext{
Alberto. "O único texto válido é o de Inocêncio IV, de 01 de outubro de 1247, que até hoje é fonte de inspiração e regra de vida para as carmelitas, que vivem na primeira, na segunda ou terceira ordem, nas Congregações, nos movimentos, nas confrarias ou nas Reformas" (Mesters, p.16- 24). "O texto literal da regra é intocável, uma vez que, tem como conteúdo valores imutáveis (...) a regra é atualizada para os religiosos nas diversas Reformas que a ordem faz no decorrer de sua existência". Ver Bayón, 2001, p.20-21.

${ }^{20}$ Esses quarenta anos nos remetem a um tempo bíblico de espera e de provações. O próprio Elias passou quarenta dias e quarenta noites caminhando até subir a Montanha de Deus (Horeb) (1Rs19, 7-8). Remetem também aos quarenta anos que o povo de Israel levou até obter a liberdade (Ex, 21-31), além dos quarentas dias que Cristo passou no deserto (Mt 4, 1-11).

${ }^{21}$ Portugal experimentou entre os religiosos e religiosas que ali habitavam o estilo de vida pautado no eremitismo e da mística; as principais contribuições para o advento deste "movimento" eremítico se revelaria a partir da divulgação dos textos de autores - religiosos - das próprias experiências que tiveram como "os frades de Santa Cruz de Coimbra que publicaram, em português, numa tradução de frade Jerónimo Brás de Barros, o Espelho de Perfeição. (Serafim, 2001). Ver também emBorges,2004.

${ }^{22}$ Era filho de D. Álvaro Gonçalves Pereira, Prior da Ordem do Hospital de São João de Jerusalém. Nuno Álvares Pereira desempenhou inúmeros cargos na Corte Portuguesa. Ele se destacou no cenário Português devido aos empreendimentos relativos à construção de igrejas e mosteiros. Ingressou na Ordem do Carmo em 1423 (como irmão terceiro), instituição fundada por ele em 1389. Permaneceu irmão desta ordem até sua morte, em 1431. Foi canonizado somente em 2009 pelo Papa Bento XVI. Disponível em: <www.historiadeportugal.info/nuno-alvares-pereira/>. Acesso em 11 de agosto de 2014. Ver também em: Bayón, 2001, p.51-61.

${ }^{23} \mathrm{Em} 1755$ um terremoto que atingiu a região de Lisboa danificou gravemente o convento. (Bayón, 2001)
} 
mais particularmente aos monges; portanto, esses homens e mulheres,mesmo não abandonando suas vidas cotidianas, puderam experimentar e participar de uma espiritualidade mais profunda e ter uma relação mais intimista com o sagrado, objetivando alcançar a salvação de suas almas. Nas palavras de William Martins, tornavam-se Membros do Corpo Místico, onde:

\begin{abstract}
A ligação próxima das ordens terceiras aos religiosos mendicantes estendia àqueles privilégios de caráter espiritual, entre os quais se contavam numerosas indulgências aplicadas à salvação das almas. Tornavam-se, assim, evidentes as vantagens que separavam o irmão terceiro do simples fiel da Igreja.(Martins, 2009. p.42)
\end{abstract}

No entanto, o primeiro estatuto conhecido da Ordem Terceira do Carmo em Portugal, remonta ao século XVII. A Ordem Terceira do Carmo de Lisboa foi fundada em 1629, e a capela dos terceiros, em 1638, conforme consta na crônica dos carmelitas (Bayón, 2001).Em Lisboa, frei Pedro de Melo divulgou esta ordem por volta da primeira metade do século XVII, admitindo a entrada na congregação, de alguns nobres mais proeminentes da Corte, como fidalgos e também pessoas de baixa condição, mas que não tivessem "defeito no sangue" (Martins, 2009. p.137). ${ }^{24}$ Este frade redigiu, em 1630, o primeiro compêndio espiritual em língua portuguesa, dedicado aos irmãos terceiros do Carmo (Martins, 2009. P.73-75), cujo título era:Regra e o modo de vida que devem observar os terceiros Carmelitas.

Outras publicações da regra, destinada aos irmãos terceiros foram escritas, como a regra publicada em Lisboa, em 1644, por Pedro da Cruz Juzarte (Bayón, 2001). Já no início do século XVIII, Pe. José de Jesus Maria editou, também em Lisboa, sua obra intituladaThesouro Carmelitano; este livro circulou tanto em Portugal como no Brasil. Segundo Balbino Bayón, todas as regras destinadas as ordens terceiras, que surgiram no Reino, tinham como modelo a elaborada pelo reverendíssimo geral do Carmo observante, Theodoro Stracio, que a traduziu e publicou em língua portuguesa, em 1637.

Já no final do século XVIII, foi lançado mais um livro em Lisboa, escrito pelo Pe. Miguel de Azeredo, intitulado Regra da Ordem Terceira da Mãe Santíssima do Monte do Carmo. Esta obra contribuiu, para mudar o conceito de votos praticados pelos terceiros, pois até aquele momento, segundo a obra de Stracio, havia uma obrigação dos ingressantes nas ordens terceiras em fazer os votos, igualmente, destinados aos religiosos. A partir desta obra, do Pe. Miguel de Azeredo, os irmãos podiam ser admitidos de duas formas: "podia obrigar-se

\footnotetext{
${ }^{24}$ A expressão "Defeito de sangue" refere-se a todos que não professavam a religião Católica e de origem social e racial não reconhecidos pela sociedade da época, como escravos, índios, judeus, etc. in. Ver mais emBorges, 2005.p 53 e tambémSalles, 2007.p 69-85
} 
gravemente ou levemente ao seu cumprimento" (Bayón, 2001, p.490). Com esta nova regra, os irmãos terceiros propunham, apenas, observar a obediência e a castidade.

Alguns irmãos terceiros de Vila Rica tiveram acesso a essa obra do Pe. Miguel de Azevedo, pois este livro, como foi possível observar, em nossas pesquisas, pertenceu a um irmão desta Vila ${ }^{25}$.

\section{Estabelecimento da Ordem Terceira do Carmo em Minas Gerais}

Os primeiros colonizadores, que vieram para a região das Minas, procuravam desbravar as montanhas à procura de metais preciosos. Segundo Diogo de Vasconcelos, em "1699, Miguel Garcia, natural de Taubaté, foi o primeiro que descobriu num córrego que faz barra no Ribeirão do Carmo" (Vasconcelos, 1999. p.178),os metais tão desejados. O território, que até então eram habitados por "índios e feras", foi sendo transformado num importante núcleo urbano(Souza,1999). Por volta da primeira década do século XVIII, chegaram às Minas, muitas pessoas atraídas pela fama do abundante mineral: "calculava-se, com razoável grau a possibilidade, em 1709, que havia umas trinta mil pessoas, ocupadas em atividades mineradoras, agrícolas e comerciais em Minas Gerais” (Boxer, 2000, p.72).

Diante desse panorama, em constante migração ao novo território colonizado, as autoridades metropolitanas, logo cuidaram de impor uma legislação para a região. Inúmeras medidas foram tomadas pela Coroa, a fim de controlar o fluxo migratório,colocando regras para a fixação no espaço minerador da América portuguesa. De acordo com Charles Boxer, o alto número de pessoas, vindas de todas as partes da Colônia e também de Portugal, que chegavam ou passavam pela região, aguçou, também, a atenção da Coroa, pois a drenagem de pessoas que emigravam da "província do Minho foi suficientemente alarmante, para que a Coroa lançasse um decreto, em março de 1720, limitando drasticamente a emigração para o Brasil, que dali por diante só seria permitida com passaporte fornecido pelo governo" (Boxer, 2000, p.72).

A Coroa portuguesa decretou, ao longo do século XVIII, a proibição da fixação de ordens religiosas na região das Minas, sob a alegação que os frades eram "responsáveis pelo extravio do ouro e por insuflar a população ao não pagamento de impostos" (Boschi, 1986. p.3). Segundo Sérgio da Mata, os dois tipos de sacerdotes, que predominaraminicialmente na Capitania, foram "de um lado, os capelães; de outro, uma grande quantidade de clérigos e

${ }^{25}$ AEPNSP/OP. Regra da Ordem Terceira da Mãe Santíssima e Soberana Senhora do Monte do Carmo. Vol. 2672. Período 1790. Esta regra pertenceu ao irmão José Álvares (sic.). 
frades irregularmente estabelecidos na região" (Mata, 2002. p.93.). Logo, nas Minas, não houve a criação de conventos ligados às ordens religiosas, pois:

(...) O fato dos Eclesiásticos das ordens primeiras- Jesuítas, Carmelitas, Beneditinos e Franciscanos - não se subordinarem à Coroa nem aos Bispos diocesanos, mas à sua própria hierarquia. Mesmo considerando estes impedimentos, a Coroa não procurou afastar totalmente de Minas o trabalho missionário (...), já que, (...) orientava os bispos do Rio de Janeiro e Bahia a enviarem eclesiásticos para criar paróquias e ministrar os sacramentos. Esta política restritiva, embora endereçada principalmente às ordens primeiras, não deixava de lado o clero secular que, para se estabelecer na Capitania, precisava de uma licença de permanência para celebrar os cultos do calendário litúrgico (...) (Borges, 2005, P 57-58).

Essa política de restrição serviu mais para "limitar o número de clérigos existentes na Capitania do que para a sua exclusão" (Boschi, 1986, p.82). Todavia, o clero regular se fazia presente nas visitas às ordens terceiras, que surgiram já na segunda metade do século XVIII ${ }^{26}$.

Tal medida, tomada pela Coroa portuguesa, foi proporcionada pela ampla jurisdição que a metrópole tinha sobre os assuntos relativos à religião Católica, adquirida pela Igreja, desde o final da Idade Média. A Coroa solidificou seu laço de poder, no âmbito da religião, institucionalizada sob o regime do Padroado(Boxer, 2002), que em linhas gerais, constituía-se em

Privilégios concedidos pelo papa aos reis portugueses que se tornaram administradores com plenos poderes dos territórios recém-descobertos, para neles implantarem a fé cristã, acumulando, assim, as funções de chefe de Estado e da Igreja nas terras d'além-mar (Boxer, 2002, p.227).

Sendo assim, a Coroa impulsionou a implantação da fé Católica na região, já que “uma das primeiras indicações de colonização permanente era a ereção de uma ou mais capelas (...)"(Boxer,2000, p 74).Nas Minas, contudo, a construção dos templos ficou nas mãos das associações de leigos, que se constituíram ao longo dos Setecentos.A vida religiosa da Capitania e o incremento do culto público receberam forte impulso das associações leigas, criadas ao longo do século XVIII. Estas, geralmente, surgiram dentro das matrizes paroquiais,construindo, posteriormente, seus próprios templos. Aliadasao advento das várias irmandades, as Ordens Terceiras foram instituídas, nesta Capitania, no período Setecentista. Os seus membros estavam subordinados às regras aprovadas pela Mesa e pela Ordem Primeira, sediada no Rio de Janeiro e prestavam obediência ao comissário escolhido pelos superiores do convento a que estavam filiados.

\footnotetext{
${ }^{26}$ Essas associações de terceiros que foram fundadas nas Minas deveriam passar pelo crivo dos frades do Rio de Janeiro para a oficialização da instituição da ordem.
} 
No que se trata das Ordens Terceiras do Carmo, fundadas em Vila Rica e na Vila do Ribeirão do Carmo (Mariana), essas se ergueram, primeiramente, dentro de capelas de outras confrarias (Trindade, 1951). A Ordem Terceira do Carmo de Vila Rica, nos anos iniciais, abrigou-se na capela de Nosso Senhor dos Perdões, como mostrou os trabalhos realizados pelo Cônego Raimundo da Trindade(Trindade, 1951).

No entanto, notamos que, nas Vilas em estudo e em outras vilas da Capitania, como no caso da Vila de São João Del Rei, num primeiro momento, de formação das ditas ordens terceiras, dedicadas à Nossa Senhora do Monte do Carmo, houve a formaçãode uma irmandade composta, possivelmente, por irmãos professos oriundos de outras partes da Capitania e do Reino, que vieram para a região, atraídos pelo metal precioso. E como, geralmente, eram pessoas devotas, trouxeram consigo suas devoções particulares. Como no território mineiro não existia, antes da primeira metade do século XVIII, as ordens terceiras, os irmãos devotos de Nossa Senhora do Carmo se reuniram e formaram, portanto, uma irmandade dedicada àVirgem do Carmo.

\section{Considerações Finais}

Ao longo de sua História, a ordem carmelita sempre marcou sua presença dentro da cristandade, desde os primeiros eremitas, que se reuniram em torno da fonte do profeta Elias, até chegar aos irmãos terceiros,que se fixaram no Brasil Colonial. Com o estabelecimento dos frades, na Capitania do Rio de Janeiro, estes logo começaram a desenvolver os trabalhos em áreas missionárias, espalhadas pelo Brasil Colônia. Ficaram a cargo dos primeiros colonizadores portugueses, a implantação da devoção à Virgem do Carmo, principalmente no território mineiro. A motivaçãode pertencimento, a este corpo místico da Igreja, levou centenas de pessoas a ingressarem, neste sodalício,desde seus primórdios.

A incorporação de uma espiritualidade própria ganhou destaque, cujo principal fundamento era aobservância de suas regras e normas, isso atrelada, em uma experiência intimista com o sagrado, seja na via da solidão, próprias dos eremitas, ou na vida contemplativa, a exemplo dos frades do Carmelo, e posteriormente, expandida para todos os irmãos leigos da Ordem Terceira.

Sendo assim, a instalação da Ordem Terceira na Capitania de Minas Gerias partiu do desejo dos irmãos devotos em implantar essa fraternidade,cada vila, com seu grupo de irmãos, buscava obter sua aprovação perante às autoridades.A atuação da associação foi ampliada na 
região, tendo como principal investimento, seus cultos e ritos, atraindo mais candidatos para a filiação nesta agremiação.

\section{Referências Bibliográficas}

\section{1) Fontes Manuscritas}

\section{Arquivo Eclesiástico da Paróquia de Nossa Senhora do Pilar - Ouro Preto.}

AEPNSP/OP. Regra da Ordem Terceira da Mãe Santíssima e Soberana Senhora do Monte do Carmo. Vol. 2672. Período 1790. Esta Regra pertenceu ao irmão José Álvares (Sic.).

\section{2) Fontes Impressas e obras de referência}

MESTERS, Frei Carlos. Ao Redor da Fonte: círculos de oração e de meditação em torno da Regra do Carmo.

PEREYRA DE SAN'ANNA, Joseph (O.C). Chronica dos Carmelitas da Antiga e Regular Observância. v. I, Lisboa, (s/e), 1745-1747, p.777. Apud BAYÓN, BalbinoVelasco. História da Ordem do Carmo em Portugal.Lisboa:Paulinas, 2001.

ROMEIRO, Adriana \& BOTELHO, Angela Vianna. Dicionário Histórico das Minas GeraisPeríodo Colonial. - 3. Ed..Rev. e ampl. - Belo Horizonte: Editora Autêntica, 2013.

VIEIRA, Domingos. Thesouro da Língua Portuguesa, III, Porto, 1983.

\section{3) Livros, artigos e teses}

AGULHON, Maurice. Pénitents et Francs-Maçons de l'ancienne Provence-essai sur la sociabilité Méridionale. Paris: Fayard, 1968.

BARBOSA, Gustavo Henrique. Associações religiosas de leigos e sociedade em Minas colonial: Os membros da Ordem terceira de São Francisco de Mariana (1758-1808). 2010. Pp.137 Dissertação (Mestrado em História). Universidade Federal de Minas Gerais, Belo Horizonte, 2010.

BAYÓN, Balbino Velasco (O.C). História da Ordem do Carmo em Portugal. Lisboa:Paulinas, 2001.

BOLTON, Brenda. A Reforma na Idade Média. Século XII. Lisboa: Edições 70, 1983.

BORGES, Célia Maia. Escravos e Libertos nas Irmandades do Rosário: Devoção e solidariedade em Minas Gerais - Séculos XVII e XIX.Juiz de Fora: Editora UFJF, 2005.

Os Eremitas e o Ideal de Santidade no Imaginário Português: o

Deserto dos Carmelitas Descalços no séc. XVII». Lusitania Sacra, 23, jan-jun, 2011.

Espiritualidade Mística na Península Ibérica. Séculos XVI e XVII.

RevistaLócus,v. 10, n. 2, p.35-51, 2004.

BOSCHI Caio César. Os Leigos e o poder: Irmandades leigas e política colonizadora em Minas Gerais. São Paulo: Ed. Ática, 1986.

BOXER, Charles R.Idade do Ouro do Brasil: dores de crescimento de uma sociedade colonial. $3^{\circ}$ edição.São Paulo. Ed. Nova Fronteira, 2000.

. O Império Maritimo Português 1415-1825. São Paulo: Companhia das

Letras, 2002.

CALLOIS, Roger. O homem e o sagrado. Lisboa: Edições70, 1988. 
CAMPOS, Adalgisa Arantes. A Ordem Carmelita. Per Musi, Belo Horizonte, n.24, 2011, p.54-61.

CARVALHO, José Adriano de Freitas. O Eremitismo em Portugal na Época Moderna: Homens e Imagens, Via Spiritus, 9, 2002.

ELIADE. Mircea. O sagrado e o profano: a essência das religiões $3^{a}$ edição- São Paulo: Editora WMF Martins Fontes, 2010.

EVANGELISTA, Adriana Sampaio. Pela salvação de minha alma. Vivência da fé e vida cotidiana entre os irmãos terceiros em Minas Gerais - séc. XVIII. 2010. Pp. 337. Tese (Doutorado em Ciência da Religião). Universidade Federal de Juiz de Fora, Juiz de Fora, 2010.

LE GOFF, Jacques. São Francisco de Assis. $8^{\text {a }}$ Ed. Rio de Janeiro: Record, 2007.

MARTINS, Willian de Souza. Membros do Corpo Místico. Ordens Terceiras no Rio de Janeiro (C. 1700-1822). São Paulo: Editora da Universidade de São Paulo (Edusp), 2009.

MATA, Sérgio da. Chão de Deus: Catolicismo popular, espaço e proto-urbanização em Minas Gerais. Brasil. Séculos XVIII-XIX. Berlim: Wiss.Verl. 2002.

MENDONÇA, Nívea Maria Leite. Entre a Hierarquia e a Devoção: a dinâmica interna e o relacionamento dos Terceiros com a Ordem Carmelita em Minas Gerais (1747-1808).Pp. 155. Dissertação (Mestrado em História). Universidade Federal de Juiz de Fora, Juiz de Fora, 2015.

SALLES, Fritz Teixeira de. Associações Religiosas no Ciclo do Ouro: introdução ao estudo do comportamento social das Irmandades de Minas no século XVIII. São Paulo. 2 ed. Rev. e ampl.: Perspectiva, 2007.

SERAFIM, João Carlos G. Relíquias e propagandas Pós Trento. Via spiritus,8, 2001, 157184.

SOUZA, Laura de Mello e. Norma e conflito: aspectos da História de Minas no século XVIII. Belo Horizonte. Ed. UFMG, 1999.

TRINDADE, Cônego Raimundo. São Francisco de Assis de Ouro Preto: Crônicas Narradas pelos documentos da Ordem. Rio de Janeiro, Ministério da Educação e Saúde, 1951. (Publicações da diretoria do Patrimônio Histórico e Artístico Nacional, n.17).

VASCONCELOS, Diogo de. História Antiga das Minas Gerais. Belo Horizonte: Edição Itatiaia, 1999.

VAUCHEZ, André. A Espiritualidade da Idade Média Ocidental - Séc. VIII- XIII. Lisboa: Editora Estampa, 1995. 


\title{
A busca do Jesus histórico
}

The quest for the historical Jesus

\author{
Daniel Salomão Silva ${ }^{27}$ \\ salomaoime@yahoo.com.br
}

Resumo: A hermenêutica bíblica caminhou das posturas retórica e apologética da Antiguidade às análises críticas contemporâneas. Em paralelo, a História Eclesiástica, em moldes proselitistas, passou à atual História das Religiões, sem centralidade no Cristianismo e muito menos na Igreja. O método histórico-crítico, causa e produto desta evolução, contribuiu imensamente para o entendimento da elaboração dos textos bíblicos, permitindo uma visão mais madura das bases da religião, encontrando guarida mesmo entre teólogos. Aplicado à pesquisa histórica de Jesus, nascida ainda no século XVIII, pôde e pode contribuir para uma visão mais livre de preconceitos teológicos sobre a figura central do Cristianismo. O objetivo deste trabalho é apresentar a evolução do método histórico-crítico nas abordagens do Cristianismo em geral e a evolução da pesquisa histórica sobre a vida de Jesus, especificamente.

Palavras-chave: Jesus histórico, método histórico-crítico, hermenêutica bíblica

Abstract: Biblical hermeneutics has moved from the rhetorical and apologetic positions of Antiquity to contemporary critical analyzes. At the same time, Ecclesiastical History, in the form of proselytizing, has became the History of the Religions of today, without centrality in Christianity, much less in the Church. The historical-critical method, the cause and product of this evolution, contributed immensely to the understanding of the elaboration of the biblical texts, allowing a more mature view of the bases of religion, finding shelter even among theologians. Applied to the historical research of Jesus, born in the eighteenth century, could and can contribute to a freer view of theological prejudices on the central figure of Christianity. The purpose of this work is to present the evolution of the historical-critical method in the approaches of Christianity in general and the evolution of historical research on the life of Jesus, specifically.

Key words: historical Jesus, historical-critical method, biblical hermeneutics

\section{Introdução}

A figura de Jesus é fascinante. Para cristãos ou não-cristãos ocidentais, é quase impossível passar um dia sem ouvir ou ver alguma referência a ele. Dividindo opiniões entre religiosos quanto a sua origem, a seu destino, ou mesmo quanto a detalhes de sua proposta ética, encontramos na permanência de sua mensagem até os dias de hoje a prova de sua importância.

\footnotetext{
${ }^{27}$ Bacharel em Ciências Humanas e graduando em Ciência da Religião pela Universidade Federal de Juiz de Fora - UFJF
} 
A pesquisa sobre o Jesus histórico, não valorizada antes do século XVIII, hoje oferece grande contribuição para uma compreensão mais profunda do contexto histórico e social dos Cristianismos originários. A tentativa de entender o contexto geográfico e cultural da memória dos seus ditos, a forma como foram teologicamente elaborados pelas primeiras comunidades cristãs, o processo de transmissão das narrativas, nos oferece uma visão mais madura sobre a figura histórica de Jesus. Ressaltando a importância da pesquisa histórica sobre Jesus, Gerd Theissene Annette Merz afirmam que, mesmo ainda pouco considerado, "numa sociedade esclarecida e numa Igreja aberta, que deseja prestar contas de seus próprios fundamentos", o trabalho de pesquisa histórica sobre Jesus "se impõe" (2004, p. 13).

De forma alguma, porém, deve-se agir com ceticismo diante dos resultados obtidos. A postura científica atual, sobretudo por se tratar de uma abordagem histórica, não possui certezas e resultados absolutos, mas probabilidades hermenêuticas. Não se pode afirmar que algo ocorreu, mas sim que algo pode ter ocorrido de acordo com determinadas fontes, de acordo com o momento atual da investigação, sob métodos específicos. Não se pode esperar pela descrição completa e inequívoca da vida de um homem que viveu no primeiro século da era cristã.

De qualquer forma, contra qualquer conclusão pessimista, o método histórico-crítico, em suas múltiplas ramificações, exerce um papel fundamental na formação do estudioso da Bíblia, pois visa esclarecer o processo de constituição dos textos e tradições bíblicas. Além disso, segundo Odette Mainville, "compreender a intenção original de um texto permite evitar interpretações equivocadas, senão inteiramente errôneas" (1999, p. 10). Saber o que algo não é já é por si só um grande passo. Mesmo diante das modernas abordagens sincrônicas, o método histórico-crítico não perderá espaço no campo dos métodos exegéticos.

Enfim, entender Jesus a partir de quaisquer fontes históricas é lidar com construções imaginativas que vão além dos "fatos" descritos nelas. As hipóteses que a própria imaginação do historiador cria em torno de seu objeto acabam por gerar uma aura de ficção em suas conclusões, o que, de forma alguma, indica arbitrariedade na pesquisa. Os diferentes métodos possuem suas regras. Deve-se sempre lembrar que os autores de cada fonte são seres humanos passíveis de falha;que, à luz do relativismo histórico, um mundo de fatores tem relevância na percepção do escritor; e que há uma distância histórica que impede que se olhe com os olhos de hoje, anacronicamente, os valores e as convicções de uma época perdida (Theissen\&Merz, 2004, p. 31). 
Diante de tamanho desafio, que mais motiva que desanima, o objetivo deste trabalho, dividido em dois capítulos, é, respectivamente, apresentar a evolução do método histórico-crítico nas abordagens do Cristianismo em geral e a evolução da pesquisa histórica sobre a vida de Jesus.

\section{Evolução do Método Histórico-Crítico nas Abordagens do Cristianismo}

O primeiro projeto historiográfico direcionado ao campo religioso coube a Eusébio de Cesareia (260-340), bispo e aliado do imperador cristão Constantino. Este autor se diferenciado evangelista Lucas, por alguns considerado o primeiro historiador da Igreja, ao manter um estilo historiográfico que valoriza a vida dos grandes homens (como Constantino), enquanto a tradição do evangelista segue o modelo das narrativas bíblicas, completamente vinculadas a um elemento querigmático e religioso.Apesar de não encontramos em Eusébio uma separação entre a esfera política e a eclesiástica, sua produção teve por recursos fontes escritas, buscando estudar o passado de forma sistemática e contribuindo do ponto de vista histórico e metodológico (Da Mata, 2010, p. 35).

Sua obra, História Eclesiástica, é repleta de fatos extraordinários misturados a possíveis dados históricos. Para o autor, o objetivo era produzir uma obra de retórica, defendendo a mensagem cristã sem se importar com a veracidade de todos os discursos. Eusébio escreve uma história com um olhar intra-eclesiástico, mais comprometido religiosa e politicamente que historicamente. De qualquer forma, foi a partir dele que se desenvolveu no Ocidente uma consciência histórica da religião cristã, apesar de ainda envolta por questões dogmáticas que não permitiam uma diferenciação entre "verdade" e "mito". História Eclesiástica inaugurou um estilo específico na história da historiografia, pois tornou-se modelo para historiadores posteriores voltados à História da Religião cristã sob uma perspectiva unicamente religiosa (Ramalho, 2013, p. 100).

Na Idade Média, a vitória do Cristianismo na Europa direcionou todo o processo histórico para uma "história da salvação". Assim, uma perspectiva histórico-filosófica, ausente na Antiguidade, foi inaugurada. Porém, com a religião preenchendo todos os espaços, destacá-la de outros aspectos da vida tornou-se desnecessário. A historiografia religiosa perdeu o sentido. Além disso, a análise de qualquer fenômeno ou tradição diversa ou contrária à visão cristã estava submetida a seu crivo exclusivista e intolerante, na contrapartida do sincero interesse dispensado pelos antigos às crenças de outros povos. O centro de interesse torna-se a trajetória institucional da Igreja. A tradição clássica é abandonada e a historiografia é reduzida à condição de crônica. Seu objetivo passa a ser apenas o de confirmar "verdades" e 
estabelecer modelos de orientação. Se um fato era embasado em uma tradição religiosa aceita, poderia ser admitido como autêntico. Naturalmente, a Bíblia era aceita acriticamente como fonte (Da Mata, 2010, pp. 36 e 37).

Para Orígenes (185-254), um representante clássico da patrística grega, o sentido literal da Bíblia conservava sua essência, sendo, porém, base para uma possível interpretação alegórica, mais coerente (Bogazet al., 2009, p. 126). Agostinho (354-430)também já admitia um sentido "espiritual" do texto bíblico, além do literal. Seu contato com Ambrósio, que repetia a recomendação de Paulo de Tarso quanto à espiritualidade além da letra, revelou-lhe o verdadeiro sentido da Escritura. Essa hermenêutica, "levantando o véu místico, revelava-me o significado espiritual de passagens que, segundo a letra, pareciam ensinar um erro" (Agostinho, 2008, p. 124). Além disso, Orígenes e Agostinho buscavam interpretar Novo e Antigo Testamentos de forma interdependente. A hermenêtica tipológica, que entendia os personagens do Antigo Testamento como figuras do Novo, "estruturava a leitura e a memória da Bíblia", de forma "bem mais decisiva do que a alegoria" (Pelletier, 2006, p. 104).

Todavia, apesar de haver propostas mais amplas de leitura da Bíblia, houve um fortalecimento da interpretação literal, controlada pela hierarquia cristã medieval, que também regulava a admissão de possíveis alegorias.Essa atitude visava impedir entendimentos arbitrários ou particulares. Para Tomás de Aquino (1225-1274), por exemplo, a interpretação literal era identificada "ao sentido desejado pelo autor divino". Essa postura, porém, seria intensificada na época do Renascimento (idem, p. 31).

$\mathrm{O}$ advento do pensamento humanista, acompanhado da crítica filológica, trouxe, porém, uma reviravolta nos estudos do Cristianismo. O incômodo crescentecom a instituição romana abriu caminho também para uma crítica às suas bases teóricas. A dúvida metódica passou a substituir a tradição como fundamento do pensamento.

O século XVI, marcado pela Reforma e consequentes guerras religiosas, foi palco de discussões no campo da historiografia cristã, marcadas pela visão protestante que associava o Catolicismo à decadência do Cristianismo, e pela contraposição católica, por outro lado(Da Mata, 2010, p. 38). A Reforma Protestante, porém, libertou as escrituras de suas amarras eclesiásticas, promovendo a avaliação crítica, ainda que subordinada a objetivos teológicos (Cabral, 2009, p. 100).Se a interpretação bíblica católica, desde cedo, submeteu-se à ortodoxia, as novas interpretações protestantes logo também cederam ao dogmatismo. A pesquisa histórica ficou submetida aos interesses apologéticos de ambos os lados (Gottwald, 2011, p. 22). Em contrapartida, o cristão agostiniano Erasmo de Rotterdam (1466-1536) foi um porta-voz do espírito crítico que emergia no Renascimento. Teólogo e filólogo, traçou os 
primeiros caminhos rumo à emancipação da exegese bíblica medieval, essencialmente dogmática. Erasmo teve importante papel no estabelecimento da crítica histórica diante das tradições bíblicas (Cabral, 2009, p. 98).

A partir do século XVII a Filologia ganha mais importância, com destaque para os estudiosos Louis Capell (1585-1658) e Richard Simon (1638-1712). Simon, profundo conhecedor das línguas bíblicas, comparou criticamente textos e traduções. Propôs uma revisão da ideia que se fazia dos autores dos livros bíblicos, talvez mais próximos do anonimato que das figuras consagradas, o que despertou controvérsias quanto ao papel da inspiração no processo de escrita e quanto à autoria mosaica do pentateuco. O conflito entre as conclusões filológicas e religiosas ficaram evidentes e não faltaram problemas com as lideranças religiosas. Todavia, esse autor não abandonou o sentido espiritual como "horizonte legítimo da leitura". Para ele, a crítica textual contribuiria para explicar o sentido literal das passagens, sem prejuízo para o dogma (Pelletier, 2006, p. 16).

Baruch Spinoza (1632-1677) foi além. Ao perceber a instrumentalização política da Bíblia pelos doutores da Igreja, a partir da tentativa anacrônica de reprodução do modelo teocrático hebraico, passou a lutar pela demolição dessa postura (Cabral, 2009, p. 107),promovendo a dessacralização da Bíblia perante a razão histórica. Entretanto, em seu Tratado Teológicopolítico, Spinoza propôs o uso da razão para o entendimento do objeto "religião revelada", e não para exegese. Seu método não tinha por objetivo "racionalizar os conteúdos e a forma de escritos religiosos, mas encontrar seu sentido, conhecendo a língua em que foram redigidos e a história do povo que os escreveu e leu" (Chaui, 2003, p. 32). Não deveria sofrer interferência da razão, "pois esta se ocupa com a verdade das coisas enquanto a exegese bíblica deve ocupar-se com o sentido dos textos" (idem, p. 30).

Removendo a Bíblia de seu pedestal, sua análise foi ampla em consequências para seu entendimento cada vez mais livre, abrindo "as portas do texto bíblico para os historiadores". Com as ferramentas da Filologia e das críticas literária e histórica, deveria se buscar o sentido do texto no texto, sem extrapolações teológicas (Pelletier, 2006, pp. 21 e 22). Diante de qualquer evento narrado, Spinoza propõe a busca de explicação no próprio cânone. Por exemplo, quanto aos milagres, procura no texto situações ou orientações de personagens importantes que atestam sua não existência. Para ele, o milagre não contradiz a razão, mas a própria Escritura. Não representa algo sobrenatural ou contrário às leis de Deus, mas sim, algo incompreensível para o ser humano (Chaui, 2003, pp. 33 e 34).

Alguns eruditos, como Gottfried Leibniz (1646-1716) e Jean Mabillon (1632-1707), adeptos do método crítico da historiografia, foram bem aceitos pelo Cristianismo institucionalizado. 
Mabillon, por exemplo, envolveu-se em discussões sobre a autenticidade de relíquias e fatos religiosos, confirmados apenas pela tradição popular. Diante do questionamento de autenticidade de alguns artefatos, preocupou-se, todavia, mais com não escandalizar os crentes que com atestar a verdade. Entretanto, sem apelar para explicações miraculosas ou submetidas apenas à fé, sua contribuição otimista para uma religião mais racional e menos fantástica é inegável (Da Mata, 2010, p. 40).

Dado o desinteresse da historiografia iluminista pela religião institucionalizada, admitida como obstáculo a um entendimento mais racional de Deus, começa-se a elaborar, no início do século XVIII, uma ciência histórica no interior das próprias igrejas, ainda que presa a contradições compreensíveis. Não se pode negar que a cientifização da historiografia do século XIX foi antecipada nas escolas de Teologia (idem, p. 48).O Protestantismo, defendendo a superioridade da Bíblica histórica e teologicamente sobre a instituição eclesiástica, havia despertado indiretamente o interesse pelo método histórico-crítico acadêmico na abordagem do texto bíblico, já amplamente presente no século XVIII. Importante é salientar que os críticos históricos não buscavam negar o caráter religioso do texto, mas entendiam seu trabalho de pesquisa como uma contribuição ao entendimento mais verdadeiro da Bíblia (Gottwald, 2011, p. 23). Johann S. Semler (1725-1791), em contrapartida, já defendia a aplicação do método histórico-crítico "com todo rigor e consequência, e não com vistas à edificação do leitor moderno" (Cabral, 2009, p. 112). Naturalmente, essa postura é indiferente à preservação ou não do aspecto religioso da Bíblia. Se Eusébio é o pai da História da Igreja, Johann L. Mosheim (1694-1755) é o responsável por sua transformação em uma disciplina independente e dotada de metodologia plena. Apenas em um contexto de crescimento da historiografia alemã, agora a partir das universidades, é possível compreender o surgimento de sua obra. É importante destacar que nas universidades alemãs pela primeira vez se determinou a distinção entre História Eclesiástica e História Universal (Heim, 2000, apud Da Mata, 2010, p. 45). Mosheim liberou a pesquisa histórica da Igreja de sua instrumentalização pela Teologia, vigente até aquele momento. Atribuiu a ela a função de investigar imparcialmente os aspectos externo e interno da comunidade cristã. Propôs um tratamento honesto das heresias, sem predileção por elas, mas sem menosprezálas. Defendeu o historiador da Igreja como um pesquisador atento a diversos contextos e campos do conhecimento, que expande seu leque de fontes cristãs e não cristãs, substituindo o método dogmático pelo pragmático. Ou seja, apesar de sua vinculação pedagógica, a História Eclesiástica poderia se desvincular de um projeto proselitista e buscar reconstituir as causas dos acontecimentos (Da Mata, 2010, p. 47). 
Importante é destacar que, já no século XIX, grandes historiadores como Leopold von Ranke (1795-1886) e Jacob Burckhardt (1818-1897), oriundos da Teologia, deram à religião grande importância em suas obras. De forma bem madura, porém, Ranke tinha plena convicção de que as verdades religiosas não estavam no escopo da ciência. Não era objetivo do método histórico comprovar ou refutar crenças religiosas. A historiografia acadêmica, todavia, diante da História Eclesiástica ou da História da Religião, mantinha certa distância. Mesmo ao tratarem de religião, os historiadores preocupavam-se principalmente com relações entre poder político e religioso. Esta separação, muitas vezes ilusória, ou esse distanciamento da religião, devia-se, em certa medida, à postura conservadora ou reacionária dos representantes das religiões no campo político. Enfim, a separação entre a História e a Teologia, que abrigava a História Eclesiástica, apenas aumentou a partir de meados do século XIX (idem, p. $53)$.

O entusiasmo pela ciência, o estabelecimento do darwinismo em contraposição ao criacionismo bíblico, bem como os avanços da Filologia abalavam intensamente a fé. A perspectiva histórico-crítica diante da religião permanecia como um risco a sua existência, segundo Franz Overbeck (1837-1905). Opondo-se ao otimismo de Leibniz e Mabillon, defendia a irreconciliabilidade entre fé e conhecimento, o qual levaria apenas ao enfraquecimento dos mitos e símbolos religiosos e à submissão da religião à ciência (Overbeck, 2001, apudDa Mata, 2010, p. 55). Overbeck antecipava, assim, o anátema de Pio X aos historiadores eclesiásticos do início do século XX. Em 1907, o papa publicou um decreto condenando os graves erros dos pesquisadores modernos, dando início a uma sequência de excomunhões e abandonos da ordem (Da Mata, 2010, p. 64).

Porém, não se pode concluir pelo declínio da História da Igreja naquela época. O historiador e teólogo Adolf von Harnack (1851-1930) ampliou o conhecimento sobre a história do Cristianismo de forma ímpar até aquele momento. Conservador quanto à política acadêmica, era contra a transformação das faculdades alemãs de Teologia em faculdades de História ou Ciência da Religião, apesar de defender o método histórico como único método adequado de se estudar as religiões. A História e a Filologia, quando aplicadas à religião, deveriam permanecer ligadas à Teologia, buscando evitar a renúncia à centralidade do Cristianismo. Para Harnack, a religião cristã era definitivamente superior às demais. Polemizava, com esta opinião, com a visão de Friedrich Max Müller (1823-1900), defensor da pesquisa ampla sobre as religiões como mecanismo até mesmo de se entender a própria religião. Torna-se possível, a partir desse momento, pensar em uma História das Religiões (idem, p. 57). 
Com o avanço de certas disciplinas, como a Psicologia, a Etnologia, a Linguística e a Sociologia, diversos pesquisadores passaram a direcionar seu interesse às origens e funções da religião no sentido amplo. Influenciada pelo evolucionismo da Biologia, a ideia de "evolução religiosa" fez todo sentido, mesmo que por poucas décadas. O principal legado dessa geração do fim do século XIX, entretanto, foi a progressiva articulação do método histórico com o método tipológico-comparativo. Max Müller, pioneiro na História das Religiões e possível criador do termo "Ciência da Religião", defendia o método comparativo como fonte de um conhecimento superior (ibid., 58).

Quanto aos estudos bíblicos, não se pode negar que as modificações sociais da modernidade, bem como o uso cada vez maior do método científico, permitiram um novo olhar. A Bíblia libertou-se de uma abordagem religiosa exclusivamente doutrinal e eclesiástica. As novas ciências abriram diversas possibilidades de pesquisa sobre o texto bíblico (Gottwald, 2011, p. 20). No passar dos séculos, muitos métodos de estudo foram desenvolvidos, modificados ou mesmo substituídos, compondo ainda hoje um leque de perspectivas legítimas que contribuem para um entendimento amplo do texto religioso. A existência de tantos métodos tem por consequência a saudável relativização de seus resultados específicos (idem, p. 21).

O interesse pelos estudos sobre a religião fora do controle da Teologia passou a crescer e mesmo conferências sobre o tema, patrocinadas por benfeitores não vinculados ao ambiente universitário, passaram a ser realizadas. O fim do século XIX e o início do XX foram marcados pela criação de cátedras de História ou Ciência da Religião nas universidades dos países europeus. O Cristianismo ou a História da Igreja não mais monopolizariam as discussões, mas teriam seu entendimento engrandecido diante da comparação com as demais tradições religiosas. Porém, de forma diferente da moderna História das Religiões, o Cristianismo ainda teria centralidade na pesquisa, como a conferia Ernst Troeltsch (18951923). O etnocentrismo ocidental-cristão permaneceria vigente por um bom tempo e ainda hoje é incentivado por projetos missionários de fortes instituições religiosas (Da Mata, 2010, p. 62).

Enfim, partindo do campo da História da Igreja e dos estudos bíblicos, a História das Religiões tem hoje variadas formas de abordagem e perspectiva analítica. Os pressupostos teológicos não mais são aceitáveis no estudo religioso. A centralidade dada ao Cristianismo não é mais pretendida e o objeto de estudo ultrapassa as religiões institucionalizadas, abrangendo o fenômeno religioso em todas as suas formas. A Teologia deixa de ser base da pesquisa para ser apenas um discurso religioso específico que pode ser alvo de estudo(idem, 2010). 
O método histórico-crítico, bem como as preocupações hermenêuticas, estão na base da pesquisa histórica sobre Jesus. A partir do século XVIII, ganha força o olhar crítico sobre sua imagem construída a partir da tradição e dos antigos textos cristãos, passando pela abordagem essencialmente racionalista de alguns autores, oscilando entre um otimismo quase religioso e um ceticismo, até chegar às posturas contemporâneas mais abrangentes e menos pretensiosas.

\section{Históra da Pesquisa Sobre a Vida de Jesus}

A história da pesquisa sobre Jesus é marcada pela oscilação entre momentos de distanciamento e aproximação da figura do Cristo, de confiança e desconfiança das fontes e de crença e descrença na própria utilidade ou possibilidade de uma visão histórica de Jesus. Seriam verdadeiras as histórias narradas nos evangelhos? Se pudéssemos confirmar alguma informação, seria possível, com os olhos de hoje, compreender realmente as narrativas?

Até o século XVIII não foi dada importância significativa à investigação histórica sobre Jesus. Não era teologicamente considerável a preocupação com o homem Jesus, mas com o Cristo ressuscitado. Desde que as afirmações sobre ele não estivessem em contradição com o que era admitido como óbvio em sua vida "histórica", não haveria problema (Theissen \& Merz, 2004, p. 13). Como apontado no tópico anterior, o objetivo apologético e proselitista da pesquisa religiosa antiga e medieval inibia qualquer iniciativa que pudesse ter resultado críticos à "verdade" da Igreja.

O início da pesquisa crítica é marcado pela crítica das fontes. Questionava-se se nos textos bíblicos tudo era autêntico ou se muitos dos trechos sobre Jesus não seriam derivados de mitos ou invenções. Em seguida, a partir de um relativismo histórico, dever-se-ia admitir que esse personagem estava vinculado à época em que viveu, sendo menos singular e absoluto do que sempre se pensou, mesmo que fosse possível admitir uma imagem histórica confiável. Por fim, somou-se a tudo isso uma consciência de estranheza hermenêtica. Mesmo que fosse possível obter uma visão histórica confiável e destacar nela certa especificidade em Jesus, este estaria isolado em sua cultura particular, cheia de preocupações escatológicas (idem, p. 20).

\subsection{Primeira Fase: Primeiros Críticos}

As primeiras visões críticas sobre a história de Jesus datam do século XVIII. O alemão Hermann Samuel Reimarus (1694-1768), professor de línguas orientais em Hamburgo, foi um pioneiro na tentativa de enxergar racionalmente a vida do Cristo, fortemente influenciado pelo 
pensamento iluminista. Com ele começa a abordagem em perspectiva puramente histórica das narrativas dos evangelhos (Theissen \& Merz, 2004, p. 20).

Reimarus traçou uma forte distinção entre as pregações de Jesus e os ensinamentos dos apóstolos nos Evangelhos. A mensagem político-messiânica de Jesus e a divulgação pelos apóstolos de um Cristo sofredor e ressuscitado é incompatível. Esta discrepância, segundo ele, é explicada por uma teoria de fraude objetiva. Os discípulos, evitando a imagem de fracasso de seu mestre, roubaram seu cadáver e anunciaram a ressurreição quando o corpo não podia mais ser reconhecido (idem, p. 21).

Para Reimarus a mensagem de Jesus é apenas compreensível dentro de um contexto judaico. Jesus não se preocupou em explicar, por exemplo, a expressão "Reino dos Céus", o que indica seu sentido costumeiro e conhecido na cultura em que vivia. Jesus atuou dentro da religião judaica e aceitou suas expectativas messiânicas (Schweitzer, 2009, p. 28). Para compreendê-lo historicamente é preciso abandonar a postura dogmática cristã e admitir que "o mundo mental no qual Jesus se movia era essencialmente escatológico" do ponto de vista judaico (idem, p. $35)$.

Jesus pode muito bem ter realizado curas de aparência miraculosa para a visão da época, mas os outros milagres não têm base segura em fatos e foram inseridos para indicar a repetição das histórias fantásticas do Antigo Testamento que dariam autoridade ao messias (ibid., p. 31).

Enfim, nunca esteve em seu projeto a fundação de uma nova religião (ibid., p. 29). A promessa de Jesus era de um reino terreno, não espiritual. Para Reimarus, o Cristianismo que se desprendeu do Judaísmo é uma invenção dos apóstolos (Theissen \& Merz, 2004, p. 21).

Esta primeira fase é também marcada pelas visões racionalistas da vida de Jesus. Inicialmente, a postura racionalista é aplicada apenas aos seus ensinamentos, excluindo a questão do milagre. Johann J. Hess (1741-1828) propunha buscar no milagre a lição ética antes de qualquer outra coisa (Schweitzer, 2009, p. 44). O uso de paráfrases das frases atribuídas a Jesus com o intuito de explicá-las sem preocupações estéticas é uma marca destas obras (idem, p. 43).Os primeiros autores racionalistas ainda permitem a intromissão do sobrenatural nos eventos da vida de Jesus, o que será rechaçado por seus sucessores (ibid., p. 51).

Heinrich E. G. Paulus (1761-1851) já pode ser considerado um racionalista pleno. Dedicou-se à explicação racional dos milagres, entendendo-os como fatos naturais não compreendidos pelos que os testemunharam (ibid., p. 68). Preocupou-se também com a ideia de messianidade de Jesus e com o episódio da traição de Judas. Sua Vida de Jesus levantou enorme oposição e, junto com a escola exclusivamente racionalista, recebeu seu golpe de misericórdia alguns anos depois por Strauss (ibid., p. 73). Ainda como racionalistas, pelo menos na abordagem da 
vida de Jesus, estão Karl A. Hase (1800-1890) e Friedrich E. D. Schleiermacher (1768-1834). Também se apegam à explicação racional do milagre, mas sem a confiança ingênua nessa forma de abordagem, já com algum ceticismo. Todavia, sob outro aspecto, superam seus antecessores ao tentar resolver "a conexão íntima dos eventos do ministério de Jesus" (ibid., p. 77).

David Friedrich Strauss (1808-1874), filósofo e teólogo alemão, publicou suaVida de Jesus em 1835, obra que incomodou e recebeu uma série de refutações, rendendo ao seu autor "proscrição social por toda a vida" (ibid., p. 22). Tornou-se centro de uma polêmica sem precedentes, pois, de forma semelhante à postura já adotada à época quanto aos textos do Antigo Testamento, defendeu a formação mítica da tradição sobre Jesus, uma "interpretação alegórica" (Da Mata, 2010, p. 50). Antes de Strauss, já quanto ao Novo Testamento, o conceito de mito era aplicado apenas aos eventos antes do batismo de Jesus e depois de sua ressureição, relegando à explicação racionalista os demais eventos de sua vida (Schweitzer, 2009, p. 101).

Como síntese, no sentido hegeliano, entre a supervalorização ingênua dos milagres e a excessiva racionalização que reduzia o Cristo a um homem comum, estaria o mito como tradução inconsciente das expectativas dos seus contemporâneos (Theissen \& Merz, 2004, p. 22). Os evangelhos sinóticos seriam compostos por diversas camadas de lendas e narrativas algumas vezes sobrepostas ou cruzadas (Schweitzer, 2009, p. 105). Naturalmente, essas narrativas sobre Jesus teriam como base algum fato histórico, mesclado a mitos posteriormente (idem, p. 106). Entretanto, em contraposição à visão de Reimarus, Strauss não atribui a presença de componentes a-históricos "a uma fraude deliberada, mas a um processo inconsciente de imaginação mítica" (Theissen \& Merz, 2004, p. 21).

Coube a Strauss também o pioneirismo em atribuir ao Evangelho de João uma estruturação a partir de premissas teológicas, fazendo-o menos confiável historicamente. Para Theissen e Merz (2004, p. 23), o ponto fraco da crítica de Strauss está em considerar os textos atribuídos a Mateus e Lucas mais antigos, sendo o Evangelho de Marcos apenas "um excerto de ambos". Do lado francês, Joseph-Ernest Renan (1823-1892) destacou-se pela publicação de Vida de Jesus, em 1863. Partindo de uma visão descomprometida com crenças ou interesses religiosos, propôs-se a narrar uma história mais próxima da "realidade" em que acreditava, sem milagres, mas obscurecida pela imaginação popular. Acreditava na possibilidade de contato mais próximo com "relatos originais"sobre Jesus, o que, naturalmente, é muito difícil, dada a antiguidade dos textos a que se tem acesso. Para ele, entretanto, longe da posição ideal em que foi colocado, Jesus seria um homem excepcional (Renan, 2006, p. 411).A indignação 
diante de sua obra foi grande o suficiente para provocar seu afastamento do cargo de professor de línguas semíticas na França (Schweitzer, 2009, p. 209). Em meio a suas narrativas de objetivo histórico, Renan abusou de certa imaginação artística, o que, segundo Schweitzer (idem, p. 212), invalida seu plano de trazer a "verdadeira" vida de Jesus. Em relação aos milagres e fatos extraordinários atribuídos aoCristo, Renan explicou-os de forma racionalista como fingimentos e mentiras de Jesus e dos apóstolos (ibid., p. 215) ou pela imaginação de seus contemporâneos (Renan, 2006, p. 19), pois não havia método empírico de confirmá-los. Esta primeira etapa, que contou também com outros pesquisadores de peso, foi sucedida por um período de grande otimismo quanto à possibilidade de reconstrução histórica da vida de Jesus.

\subsection{Segunda Fase: Otimismo}

Nesta fase, a esperança de se reconstruir a real personalidade de Jesus tornou-se forte. A partir de uma elaboração histórico-crítica da história da figura central do Cristianismo, buscou-se renovar a fé cristã abandonando os dogmas da Igreja (Theissen \& Merz, 2004, p. 23).

Christian H. Weisse (1801-1866) pode ser considerado o continuador direto de Strauss. Seu objetivo, a partir dos textos evangélicos, é encontrar uma conexão geral entre as narrativas neotestamentárias que se caracterize como historicamente correta quanto à vida de Jesus. A partir disso, poderia definir melhor os limites do mito nessas histórias. Weisse defende a ideia de que o Evangelho de Marcos teria sido o primeiro a ser escrito, contrariando Strauss neste aspecto. Analisando detalhes gráficos, como trechos possivelmente derivados de tradições orais, muitas vezes desconexos ou fragmentários, conclui pela origem a partir de reais relatos de Pedro, sem descartar a "tendência mitopoiética" já presente. Os demais evangelhos sinóticos basicamente conteriam comentários sobre as passagens originais de Marcos, além de trechos de uma segunda fonte. A simplicidade do Evangelho de Marcos seria o argumento mais forte no pensamento de Weisse (Schweitzer, 2009, pp. 148, 149 e 153). É interessante notar que esse autor é o primeiro a lidar com alguns dos problemas dos evangelhos a partir também de considerações psicológicas. Por exemplo, admite a crença na ressurreição como posterior a morte de Jesus, mas a partir de possíveis causas psíquicas (idem, p. 155).

O teólogo Christian G. Wilke (1788-1854) vem em apoio a Weisse quanto à prioridade do Evangelho de Marcos. Em relação ao Evangelho de João, fica ao lado de Strauss ao rejeitá-lo como fonte histórica. Weisse preferiu ficar em uma posição intermediária, admitindo alguma 
validade no quarto evangelho, apesar de descartá-lo de sua análise histórica (ibid., p. 150 e 152).

O que é bem claro na etapa liberal da pesquisa sobre Jesus é a visão crítico-literária das fontes mais antigas sobre sua vida. Logo, além da defesa de Marcos como primeiro evangelho, é admitida por Weisse e Wilke a existência de uma fonte (Q) contendo ditos de Jesus, ausentes em Marcos, mas presentes nos demais sinóticos. Essas duas fontes seriam, então, confiáveis para a busca do Jesus histórico (Theissen \& Merz, 2004, p. 23). A fonte Q, também chamada Fonte dos Ditos, é uma "grandeza inferida"e o material mais importante para a reconstrução da mensagem de Jesus, ainda segundo Theissen e Merz (idem, p. 48).

Um grande representante desta fase é o teólogo protestante Heinrich Julius Holtzmann (18321910). Metodologicamente, parte de uma crítica literária dos textos admitidos como mais antigos, contribuindo para o desenvolvimento da teoria das duas fontes. De Marcos retira a estrutura básica da vida de Jesus, entendendo como certa a autoconsciência de Jesus como o Messias formada na Galileia e sua revelação como tal aos discípulos (Mc, 8) (ibid., p. 23). Não levanta oposição ao uso do Evangelho de João junto aos sinóticos em sua pesquisa. Sustenta a importância de se reconstruir de forma independente a vida de Jesus a partir das passagens joaninas e sinóticas para, enfim, compará-las de forma enriquecedora (Schweitzer, 2009, p. 232).

Enfim, como um dos resultados da pesquisa liberal sobre Jesus, chegou-se a uma posição quanto à relação entre os evangelhos sinóticos e o de João. Apesar da postura mediadora entre essas fontes na maior parte dos pesquisadores dessa fase, mas talvez até mesmo por ela, podese concluir pela insustentabilidade de uma conciliação (idem, p. 244).

Tanto os racionalistas da primeira fase quanto os otimistas liberais exploraram suas teorias até o limite e, inconscientemente, abriram caminho para uma visão histórica posterior mais profunda, a partir de suas limitações. Acreditando encontrar a personalidade de Jesus impressa nas fontes (Theissen\&Merz, 2004, p. 23) e buscando explicar a ligação entre os atos de Jesus e o eventos de sua vida por uma abordagem psicológica, nas entrelinhas dos textos, demonstraram sua inaplicabilidade (Schweitzer, 2009, p. 247).

\subsection{Terceira Fase: Ceticismo}

O otimismo da fase anterior foi logo substituído por um ceticismo quanto às possibilidades da pesquisa histórica sobre Jesus. Na virada do século XIX para o XX, alguns fatores contribuíram para o pessimismo dos pesquisadores (Theissen \& Merz, 2004, p. 24). 
O teólogo alemão luterano Georg William Wrede (1859-1906) apontou o caráter tendencioso das primeiras fontes sobre Jesus, mesmo sobre o Evangelho de Marcos, que conteria a expressão da fé dos primeiros cristãos. Esse evangelho seria a concretização literária das ideias.A crença desenvolvida pelos discípulos após a ressurreição encobre os dados históricos pré-pascais, logo a confiança nos registros dos evangelhos é abalada (idem, p. 24).Segundo Schweitzer (2009, p. 369), em acordo com Wrede, as conclusões sobre Jesus a partir de Marcos provêm de conjecturas psicológicas a partir da leitura, nas entrelinhas, de muitas coisas ausentes no texto. A construção histórica de cada pesquisador viria, enfim, a partir da seleção de trechos que reforçassem suas convicções e da rejeição dos que as contrariassem (idem, p. 370).

Albert Schweitzer (1875-1965), filósofo e teólogo, buscou demonstrar que todas as imagens do Cristo apresentadas até o momento são projeções do ideal ético de cada autor, de suas expectativas sobre o Mestre, influenciando fortemente qualquer conclusão histórica (Theissen \& Merz, 2004, p. 24). O Jesus concebido teologicamente nunca existiu: é "uma figura projetada pelo racionalismo, dotado com vida pelo liberalismo, e revestido pela moderna Teologia com uma vestimenta histórica" (Schweitzer, 2009, p. 439). Reconhecendo o fracasso da pesquisa histórica, defendeu que Jesus só pode ser percebido como "espiritualmente surgido dentro dos homens" (idem, p. 440).

Karl Ludwig Schmidt (1891-1956), teólogo protestante, duvidou da possibilidade de estabelecimento de uma cronologia segura da vida de Jesus, dado o caráter fragmentário do texto evangélico. O autor do Evangelho de Marcos teria reunido e organizado esses fragmentos cronológica e geograficamente em período posterior. E, segundo ele, de forma semelhante a Schweitzer, mesmo os pequenos fragmentos são adequados às necessidades ideológicas das comunidades em que surgiram, traduzindo imperfeitamente uma biografia (Theissen \& Merz, 2004, p. 24). Tanto Schmidt quanto o teólogo Rudolf Karl Bultmann (1884-1976) foram expoentes da escola crítica das formas, ou seja, de um método crítico que busca a investigação das formas embrionárias dos evangelhos, em um período anterior à sua redação, em sua forma oral (Mcdowell, 2001, apud Dos Santos, 2010, p. 13).

Enfim, Bultmann entendeu que todo o texto do Novo Testamento teria por objetivo apenas o anúncio da mensagem cristã, em detrimento da figura histórica de Jesus. Sua teologia dialética contrapôs radicalmente o Cristo e o mundo: apenas nas ocasiões do nascimento e da crucificação de Jesus haveria o encontro desses dois opostos. Reforçou ainda a visão de Samuel Reimarus quanto à ligação teológica e cultural de Jesus com o Judaísmo. O Cristianismo teria surgido apenas no episódio da Páscoa, entretanto, Bultmann compreendeu 
que toda a construção pós-pascal não poderia ser inteiramente independente da vida física do Messias. Baseado nessa ideia, um otimismo ressurgiu no meio acadêmico (Theissen \& Merz, 2004, p. 25).

\subsection{Quarta Fase}

Não mais tentando contrariar integralmente a visão da Igreja, uma nova pergunta é proposta: algo na construção teológica da figura de Jesus tem algum fundamento em seus atos prépascais? Afinal, toda a elaboração da doutrina cristã nos escritos mais antigos se apoia em uma figura humana, terrena. Logo, seria possível encontrar um mínimo de autenticidade confiável ao se excluir tudo o que tem origem no Judaísmo e no Cristianismo primitivo, ou seja, ao se retirar qualquer interpretação possivelmente tendenciosa oriunda de interesses religiosos. Utilizando como ferramentas tanto a História das Religiões quanto a História das Tradições, no que se denominou "critério da diferença", esta fase se valeu de métodos comparativos visando "garimpar" algo de histórico nos primeiros textos sobre Jesus. Um dos grandes representantes dessa fase, discípulo de Bultmann, é o teólogo Ernst Käsemann (19061998), que tentou recuperar a visão do Jesus histórico sob essa nova perspectiva: o Jesus da História é necessário para o Cristo da Igreja. De certa forma, a doutrina cristã pós-pascal, apresentada nos evangelhos, deveria ter por base momentos da pregação de Jesus (idem, p. 26).

É importante destacar também a pesquisa pelo Jesus histórico fora das lentes cristãs. Nos círculos judaicos, principalmente a partir do século XIX, nasceu um interesse pela pesquisa histórica sobre Jesus. Superando as visões antigas e medievais que deturpavam sua imagem, pesquisadores judeus passaram a avaliá-lo mais positivamente do ponto de vista histórico (Cook, 2011, p. 38). A ênfase no caráter judaico da vida e do ensino de Jesus, ainda não muito valorizados pelos estudiosos cristãos, é de grande importância para uma maior compreensão da vida desse grande judeu. Jesus tornou-se, de certa forma, acolhido pelos estudiosos judeus como uma figura importante para sua própria história. Entre eles, é visto ora como o representante de uma forte ética judaica, ora como um verdadeiro profeta, ou ainda como apenas um rebelde (Theissen \& Merz, 2004, p. 27). 


\subsection{Quinta Fase}

Os estudiosos posteriores à escola bultmaniana identificaram, porém, um claro interesse teológico na pergunta proposta por seus antecessores. Com a intenção arbitrária de fundamentar e defender a identidade cristã, separando-a de antigas heresias ou mesmo do Judaísmo, deram preferência a fontes canônicas. Nessa mais recente fase, com presença marcante de pesquisadores da língua inglesa, outros pontos passaram a chamar mais atenção. O primeiro deles é o papel histórico-social de Jesus (idem, p. 28).

O surgimento e o destino de Jesus traduzem as preocupações apocalípticas dos judeus no século I d.C., pois, como já identificado em outras épocas e sociedades, momentos de renovação são sempre marcados pela presença de uma figura profética. A partir dessa analogia, também é possível concluir que não houve solução de continuidade do ponto de vista social entre a pregação pré-pascal e a ideologia cristã pós-pascal (ibid., p. 28). E, considerando a mensagem de Jesus como um movimento de renovação do judaísmo, até mesmo de restauração do povo judaico, uma continuidade do ponto de vista teológico também passa a fazer sentido. Jesus radicalizou propostas judaicas e boa parte dateologia pós-pascal foi estruturada a partir de concepções veterotestamentárias (ibid., p. 29).

Em segundo lugar, as fontes cristãs não-canônicas passaram a ser mais valorizadas, às vezes até exageradamente. É um consenso a necessidade de se explicar a variedade de visões sobre Jesus também através de fontes não ortodoxas. A Fonte dos Ditos (Q), já citada, e o Evangelho de Tomé, encontrado em 1945, ganharam muita importância. Essas duas fontes contêm quase que exclusivamente sentenças de Jesus, sem narrativas de milagres e da ressurreição. O teólogo irlandês John D. Crossan (1934-), por exemplo, não considera os evangelhos canônicos como fontes primárias, mas apenas outros textos considerados mais antigos, como alguns trechos do Evangelho de Tomé (ibid., p. 29). Para ele, "os evangelhos não são nem histórias nem biografias, mesmo dentro das antigas tolerâncias para esses gêneros. Cada um é o que foi por fim chamado - um Evangelho ou Boas Novas" (Crossan, 1995, apud Dos Santos, 2010, p. 20).Quanto ao valor histórico, Crossan considera como mais corretas as informações "a partir de dados combinados do historiador judeu Flávio Josefo, no final do primeiro século, e do historiador Tácito de Roma, no início do segundo século da Era Comum" (Gagliardo, 2010).

Caminham em direção oposta, neste aspecto, Geza Vermes (1924-) e Josh McDowell (1939-). Vermes entende que, se o objetivo dos evangelistas não fosse biográfico, mas ideológico, as 
formas literárias mais adequadas, mesmo à época, seriam as de "cartas, panfletos ou sermões" (Vermes, 2006, apud Dos Santos, 2010, p. 22).

Alguns estudiosos também têm destacado o caráter histórico, mesmo que frágil, do Evangelho de João, tão ignorado pelos historiadores. O biblista John Paul Meier (1942-), presumindo uma independência entre o quarto evangelho e os sinóticos, admite até a possibilidade de aquele estar historicamente mais correto. Outros pesquisadores também têm se dedicado atualmente à narrativa joanina (Faria, 2013).

E, como terceiro ponto, aprofundando ainda mais discussões anteriores sobre o tema, a ligação de Jesus com o Judaísmo é fortemente estabelecida, sendo deixado de lado o critério da diferença. O teólogo e professor de Novo Testamento Gerd Theissen(1943-) entende Jesus como o fundador de um movimento de renovação dentro do Judaísmo. Já o norte-americano Ed P. Sanders (1937-), também em acordo com Theissen, vê a mensagem de Jesus como um convite à restauração do povo judaico. Outros estudiosos desta fase, porém, paradoxalmente enxergam o Cristo como um judeu fortemente influenciado pela cultura grega, que está à margem do Judaísmo. Entre eles destacam-se Burton L. Mack (1931-) eo já citado John D. Crossan. Entretanto, independentemente das divergências, a nova busca pelo Jesus histórico tende a um critério de plausibilidade, menos pretensioso. Tudo o que é plausível no contexto judaico e torna compreensível o surgimento do Cristianismo primitivo poderia ser histórico (Theissen \& Merz, 2004, p. 29).

\section{Considerações Finais}

Segundo Albert Schweitzer, "não há tarefa histórica que revele o verdadeiro interior de um homem como a de escrever uma Vida de Jesus" (2009, p. 14). Pesquisar a passagem deste homem incomparável pela Terra é colocar em evidência as próprias expectativas sobre ele. Sob qualquer das diversas bandeiras cristãs, ou mesmo fora de todas elas, a mensagem de Jesus atinge todas as angústias e anseios do homem moderno, acreditando ou não em sua autenticidade. Para alguns, segundo Theissen \& Merz, "a diversidade de imagens de Jesus levanta a suspeita de que os retratos de Jesus sejam na verdade autorretratos de seus autores" (2004, p. 31). Porém, podem ser mais que isso. Esses mesmos autores indicam que o fato de haver pontos indiscutíveis, atribuíveis especificamente a Jesus, em quaisquer de suas biografias, criam relativa unidade, o que não impede a ação da imaginação histórica do pesquisador (idem). 
Com pretensões talvez menores, a pesquisa histórica sobre Jesus na atualidade certamente tem o que acrescentar. A partir da retomada da identificação do Cristo com o Judaísmo, apontada anteriormente, mas intensificada na quinta fase, surgem novos pontos de vista sobre as ações e expectativas deste grande judeu. Buscando a renovação do Judaísmo, a restauração do povo judaico, ou mesmo estando à margem da religião de seusancestrais, é certo que a linguagem religiosa e a situação da população embasaram sua pregação.

Em um mundo em que o fundamentalismo religioso permanece forte, mesmo nos círculos cristãos, propor uma leitura da Bíblia de forma mais tolerante e crítica, apresentando um Jesus menos mítico, longe de diminuir a relevância da religião, permite a ela uma proximidade maior ao intelecto e ao sentimento contemporâneos. Não é mais tempo de crença dogmática, mas de fé racional. Sem afetar as expectativas religiosas, que estão fora do campo científico, uma visão mais crítica da Escritura ajuda o religioso a diferenciar regras e pensamentos de uma época distante do cerne atemporal da mensagem do Cristo.

\section{Referências}

AGOSTINHO. Confissões. São Paulo: Martin Claret, 2008.

BOGAZ, Antônio S., COUTO, Márcio A., HANSEN, João H. Patrística: caminhos da tradição cristã. $2^{a}$ ed. São Paulo: Paulus, 2009.

CABRAL, Jimmy Sudário. Bíblia e Teologia política: escrituras, tradição e emancipação. Rio de Janeiro: Mauad X, 2009.

CHAUI, Marilena. Política em Espinoza. São Paulo: Companhia das Letras, 2003.

COOK, Michael J. In: BRUTEAU, Beatrice. (Org.). Jesus segundo o Judaísmo: rabinos e estudiosos dialogam em nova perspectiva a respeito de um antigo irmão. $2^{a}$ ed. São Paulo: Paulus, 2011.

CROSSAN, John Domenic. Quem Matou Jesus? As Raízes do Anti-semitismo na História Evangélica da Morte de Jesus. Rio de Janeiro: Imago, 1995.

DA MATA, Sérgio. História e Religião. Belo Horizonte: Autêntica, 2010.

DOS SANTOS, Samuel Nunes. Criticismo neotestamentário e os evangelhos enquanto fontes histórico-biográficas para construção de uma Vita deJesus. Revista Jesus Histórico, Universidade Federal do Rio de Janeiro, v. 4, 2010.

FARIA, Lair Amaro dos Santos. O quarto evangelho e sua historicidade. Revista Jesus Histórico, Universidade Federal do Rio de Janeiro, v. 11, pp. 9 - 19, 2013.

GAGLIARDO, Vitor Orlando. Entrevista com John DominicCrossan: "Teologia e História precisam caminhar juntas”. Revista Jesus Histórico, Universidade Federal do Rio de Janeiro, v. 5, 2010.

GOTTWALD, Norman K. Introdução socioliterária à Bíblica Hebraica. $3^{\mathrm{a}}$ ed. São Paulo: Paulus, 2011.

HEIM, Manfred. Einführung in die Kirchengeschichte. München: C. H. Beck, 2000.

MAINVILLE, Odette. A Bíblia à luz da História. São Paulo: Paulinas, 1999.

MCDOWELL, Josh. Evidência Que Exige um Veredito. Evidência Histórica da Fé Cristã. São Paulo: Candeia, 2001. v. 2.

OVERBECK, Franz. How christian is our present-day theology?Irish Theological Quarterly, n. 66, p. 50-66, 2001. 
PELLETIER, Anne-Marie. Bíblia e hermenêutica hoje. São Paulo: Edições Loyola, 2006.

RAMALHO, Jefferson. Eusébio e Constantino: início de uma igreja imperialista. São Paulo: Fonte Editorial, 2013. pp. 94-112.

RENAN, Joseph-Ernest. Vida de Jesus. São Paulo: Martin Claret, 2006.

THEISSEN \& MERZ, Gerd; MERZ, Anette. O Jesus Histórico: um manual. 2a ed. São Paulo: Edições Loyola, 2004.

VERMES, Geza. As Várias Faces de Jesus. Rio de Janeiro: Record, 2006. 


\title{
Diálogos entre o cristianismo e a Ciência Moderna: a perspectiva de Edward Grant
}

Dialogues between Christianity and Modern Science: the perspective of Edward Grant

Luiz Cambraia Karat Gouvêa da Silva ${ }^{28}$

luiz.cambraia.silva@usp.br

\begin{abstract}
Resumo: Ainda que a discussão acadêmica sobre a relação entre o cristianismo e a Ciência Moderna já conte com ampla produção nas Ciências Humanas, o assunto está longe de ter atingido a exaustão. Mitos e preconceitos permeiam os argumentos de pensadores que atuam neste caloroso embate de ideias, o que, muitas vezes, faz com que este complexo e multifacetado tema seja reduzido a modelos explicativos simplistas. Estetexto tem por objetivo colocar em debate a proposta analítica do historiador da ciência norte-americano Edward Grant que, lançando luz sobre as importantes contribuições científicas da Baixa Idade Média, ajuda-nos a reavaliar a importância da Igreja na emergência do que é comumente chamado de Ciência Moderna, evidenciando mais uma dimensão histórica do fenômeno religioso.
\end{abstract}

Palavras-chave: Edward Grant; Ciência Moderna; Baixa Idade Média

\begin{abstract}
Although the academic discussion about the relation between Christianity and Modern Science counts with an ample production in the Human Sciences, the subject is far from having reached the exhaustion. Myths and preconceptions permeate the arguments of thinkers whodedicate their work in this heated clash of ideas, which often reduces this complex and multifaceted debate to simplistic explanatory models. This paper aims to put into debate the analytical proposal of the American historian of science Edward Grant, which seeks to demonstrate the importance of scientific contributions of the Late Middle Ages and helps us to reassess the importance of the Church in the emergence of what is commonly called Modern Science, highlighting another historical dimension of the religious phenomenon.
\end{abstract}

Key-words: Edward Grant;Modern Science; Late Middle Ages

\section{Introdução}

É fato que o epíteto "Idade das Trevas", que busca caracterizar o período medieval como obscurantista, vem perdendo espaço na historiografia geral há um bom tempo. Historiadores como Le Goff, Lucien Febvre, Philippe Ariès, March Bloch, Georges Duby, Ruy de Oliveira Andrade Filho, Hilário Franco Júnior e muitos outros, se esforçaram, durante os séculos XX e XXI, em demonstrar a imprecisão desta caracterização. Entretanto, muitos

\footnotetext{
${ }^{28}$ Graduado na Universidade de São Paulo e doutorando no Programa de Pós-graduação em História da Universidade Estadual Paulista Júlio de Mesquita Filho, campus Assis; bolsista do Conselho Nacional de Desenvolvimento Científico e Tecnológico (CNPq).
} 
estudos da Historiografia da Ciênciaaindasão orientados por essa antigarepresentação sobre o período medieval. A influência de modelos historiográficos descontinuístas ${ }^{29}$, presente em estudos de pesquisadores de peso como Thomas Kuhn (2013) e Alexandre Koyré (1986),fez com que boa parte da Historiografia da Ciência relegasse a um segundo plano o estudo das influências científicas dos medievais na construção da Ciência Moderna, fazendo com quesuas atenções se voltassem ao que ficou conhecido como Revolução Científica.

Na perspectiva descontinuísta, a Idade Média foi, muitas vezes, caracterizada como um período de pouco desenvolvimento científico. Um dos argumentos mais comuns dessa corrente defende que a Ciência Moderna só pode se desenvolver por conta do fim da Escolástica medieval e a emergência do Renascimento. Para tanto, esses estudos assentam sua argumentação em modelos historiográficos triunfalistas (Magalhães, 2015),nos quais personagens como Galileu, Copérnico, Newton, Bacon e outros, têm seus feitos superdimensionados, negligenciando a importância das contribuições medievais para a elaboração de suas ideias.

Parte considerável dessa caracterização feita pelos historiadores da ciência está diretamente ligada à concepção de que a Igreja Católica foi, durante a Idade Média, um entrave para o desenvolvimento intelectual. Michael H. Shank (2012) reconhece que o fortalecimento dessa construção estereotipada acontece quando a divulgação da história da ciência se dá de modo acrítico:

O conceito grosseiro da Idade Média como um período de estagnação induzido pelo cristianismo desapareceu, no essencial, nos textos acadêmicos familiares com esse período, mas permanece pujante junto dos divulgadores de história da ciência talvez porque, em vez de consultarem os artigos acadêmicos publicados sobre o tema, os divulgadores mais recentes se baseiam de forma acrítica em seus predecessores. (Shank, 2012, p. 36)

Entretanto, historiadores das ciências têm reavaliado a suposta hostilidade do cristianismo em relação ao surgimento da chamada Ciência Moderna. Ainda que a importância da ciência medieval já tenha sido reconhecida desde, pelo menos, o início do século XX - através dos estudos de Pierre Duhem e de George Sarton -,até hoje parte considerável dos historiadores da ciência ainda negligencia essa contribuição - fenômeno

\footnotetext{
${ }^{29}$ No que se refere ao nascimento da Ciência Moderna podemos identificar, grosso modo, duas grandes perspectivas historiográficas que dominam este debate. A primeira, chamada rupturista, ou descontinuísta, entende que os séculos XVI e XVII experimentaram, nas figuras de Copérnico, Galileu, Tycho Brahe, Francis Bacon, Descartes, Newton e outros, uma quebra em relação às formas medievais escolásticas de compreender o mundo, iniciando, assim, uma nova tradição científica. Em contraposição, a perspectiva histórica continuístaprocura enfatizar a importância da ciência medieval, o que, como consequência, acaba por gerar uma reavaliação sobre os limites e alcances da Revolução Científica (Beltrán, 1995).
} 
também observado na historiografia da ciência nacional. Pretendemos, neste texto,identificar as formas como o historiador da ciência Edward Grant reconhece, principalmente na Baixa Idade Média, uma possível interdependência entre o fenômeno religioso e o científico, reavaliando a possível hostilidade entre esses dois agentes. Para tanto, separamoso trabalho em duas partes. Na primeira, veremos algumas formas estereotipadas de representação que ainda persistem em considerar a Igreja como "adversária" do pensamento científico. $\mathrm{Na}$ segunda, veremos como Edward Grant reconhece a importância da instituição religiosa para o desenvolvimento da Ciência Moderna.

\title{
Entre mitos e preconceitos
}

\begin{abstract}
O período entre os séculos IV e XVI é tradicionalmente conhecido por Idade das Trevas, Idade da Fé ou, com mais frequência, Idade Média. Todos eles rótulos pejorativos, que escondem a importância daquela época na qual surgiram os traços essenciais da civilização ocidental (Franco Jr., 2006, contracapa)
\end{abstract}

Segundo Franco Jr., a Idade Média foi um período de grande importância na edificação das bases mais fundamentais da civilização ocidental contemporânea. No que se refere à ciência esse processo não foi diferente. O próprio Franco Jr. entende que a Idade Média Central - que, em sua divisão temporal, vai do século XI ao XIII - e a Baixa Idade Média - circunscrita, de acordo com o autor, entre o século XIV e meados do XVI - foram períodos de crescimento da produção intelectual científica (Franco Jr., 2006).

A compreensão de Franco Jr. pode servir como base do entendimento contemporâneo sobre a importância da Idade Média e de como rótulos estereotipados, tais como "Idade das Trevas”, quase não encontram mais espaço nos estudos sobre esse período ${ }^{30}$.Entretanto, como vimos na Introdução, o campo da História da Ciência ainda apresenta certa resistência em incorporar esse entendimento. Boa parte dos historiadores dessa área, e de profissionais de divulgação científica, ainda reproduz uma caracterização distorcida de Idade Média na qual a ciência não pôde se desenvolver por conta de uma suposta "influência negativa” da Igreja.

Leonard Mlodinow, físico estadunidense e um dos principais nomes de divulgação científica da atualidade, é um exemplo da manutenção desse tipo de caracterização. Colunista do The New York Times e roteirista de séries de ficção científica, tal como Star Trek, é hoje

\footnotetext{
${ }^{30} \mathrm{O}$ entendimento de Franco Jr. se alinha com o dos principais cânones dos estudos medievalistas, como, por exemplo, o de Jaques Le Goff: “[...] a partir do século XI, já não se pode falar, como se falava entre os séculos XVI e XIX, de idade das trevas para designar a Idade Média, e nosso tempo reconhece nela nossa infância, o verdadeiro início do Ocidente atual, independentemente da importância das heranças judeu-cristã, greco-romana, 'barbara' e tradicional que a sociedade medieval recolheu." (LeGoff, 2016, p. 8).
} 
um importante influenciador na área de divulgação das ciências exatas. Em $O$ Andar do Bêbado, lançado originalmente em 2008, Mlodinow defende que a Idade Média, mergulhada em “crenças", não contaria com modelos "sistemáticos" de compreensão do mundo:

A revolução científica foi uma revolta contra o modo de pensar dominante na época em que a Europa emergiu da Idade Média, uma era na qual as crenças a respeito do funcionamento do mundo não eram examinadas de maneira sistemática. Os mercadores de uma cidade roubavam as roupas de homens enforcados porque acreditavam que isso ampliaria suas vendas de cerveja. (Mlodinow, 2009, p. 82-83).

Fato é que, para o autor, a Idade Média não teria desenvolvido modelos racionais de explicação do mundo físico. Crenças de outra natureza, tais como a religiosa e a mágica, teriam impedido a construção de modelos sistemáticos de compreensão de mundo. Esse tipo de representação estereotipada não fica circunscrito aos divulgadores científicos das áreas das exatas. Também podemosobservá-ladentro da própria produção voltada para a divulgação histórica. O canal de podcastEscriba Café é um exemplo ${ }^{31}$. Ainda que Christian Gurtner, fundador e editor do canal, não assuma qualquer tipo de compromisso acadêmico rigoroso, seus muito bem produzidos episódios de divulgação históricaacabam por compactuar com uma visão estereotipada da Idade Média:

\begin{abstract}
A Europa vivia uma época de abundância cultural, artística, política e religiosa conhecida como Renascimento, ou Renascença. Esse nome se deve ao fim dos escuros e ignorantes séculos da Idade Média, e a sociedade redescobria e pautava novamente o conhecimento e referências da Antiguidade Clássica. O feudalismo dava lugar ao capitalismo, a arte ganhava liberdade e prestígio, a ciência começava a avançar novamente e quase todos os aspectos da sociedade mudavam, como a música, literatura, artes visuais e arquitetura (Gurtner, 2014, 3min. 20seg., grifo nosso $)^{32}$.
\end{abstract}

Neste trecho, para que o Renascimento seja entendido como período de esplendor cultural, e para compreender o cenário social em que Leonardo da Vinci estava inserido, Gurtner caracteriza a Idade Média como um período de "séculos escuros e ignorantes", retomando a antiga representação de "Idade das Trevas". A explicação para o fim desse suposto período de obscurantismo ficaria para um outro episódio da série, Reforma Protestante. Para Gurtner, a deflagração da Reforma teria como consequência a ruptura com a

\footnotetext{
${ }^{31}$ Entendemos que, nos dias de hoje, os canais de podcast cumprem uma função fundamental na divulgação científica e histórica. Isso porque a facilidade com que os usuários têm acesso aos conteúdos faz do podcast uma ferramenta multimídia extremamente popular e de grande alcance.

${ }^{32}$ Além do podcast, o áudio, e sua transcrição, encontram-se disponíveis no site https://escribacafe.com/podcastii-leonardo-da-vinci-baa0d1flc048
} 
época medieval. Em seu entendimento, apenas a partir do momento em que a Igreja Católica perde sua hegemonia que uma "nova era" pôde florescer:

\begin{abstract}
Surgia a Igreja Luterana em várias partes. A Inglaterra cortou laços com Roma e fundou sua própria Igreja Anglicana. E assim, o protestantismo seguiu pela Europa como uma ferramenta social, religiosa e política.

Era o fim da idade das trevas(Gurtner, 2017, 23min. 40seg., grifo nosso) ${ }^{33}$.
\end{abstract}

Boa parte dos argumentosdos divulgadores científicos e históricos utilizados para justificar o "atraso científico" da Idade Média se deve a uma suposta atuação da Igreja em “coibir" a prática científica. Na realidade, esse tipo de representação possuirespaldo teórico acadêmico. Desde o final do século XIX é possível verificar esse tipo de caracterização entre pesquisadores profissionais:

\begin{abstract}
A facção cristã [no início da Idade Média] afirmou que todo o conhecimento deve ser procurado nas Escrituras e na tradição da Igreja [...]. A Igreja posicionou-se, assim, como depositária e árbitra do conhecimento [...] Estava sempre pronta a recorrer ao poder secular para impor a obediência às suas decisões. Deste modo, escolheu um caminho que determinou toda a sua carreira futura: tornou-se um obstáculo ao avanço intelectual da Europa ao longo de mais de mil anos." (Draper, J. W. apud Shank, M. H., 2012, p. 35, grifo nosso $)^{34}$
\end{abstract}

Segundo Stephen J. Gould (2002), embora o historiador norte-americano da segunda metade do século XIXJohn William Draper não ter criado a tese que opõe Igreja à Ciência, certamente elevou esse debate a outro patamar. Muito mais incisivo que seu colega Andrew Dickson White - que se limitou a questionar o dogmatismo de tendências cristãs mais ortodoxas -,Draperteria defendido, em sua obra History of the Conflict Between Religion and Science, de 1874, a existência de uma "guerra" entre ciência e religião ${ }^{35}$, mais precisamente, a religião católica - tendo em vista que o autor partilhava do forte sentimento anticatolicista presente nos Estados Unidos do final do século XIX.

É possível verificar, no corpus de produção acadêmica do século XX, os desdobramentos desse tipo de abordagem, caso de Koestler, que defende que a emergência do

\footnotetext{
${ }^{33}$ Além do podcast, o áudio, e sua transcrição, encontram-se disponíveis no site https://escribacafe.com/podcastxv-a-reforma-7c22755d6ab9

${ }^{34}$ Trecho retirado da obra de John William Draper History of the Conflict between Religion and Science, de 1874.

${ }^{35}$ Para Gould, Draper e White teriam sido os responsáveis, no final do século XIX, pela criação do "modelo [de representação] padrão de guerra entre a ciência e a religião" (2002, p. 86). Para o historiador da ciência Richard Olson, a visão de White teria modelado a forma de se compreender o relacionamento entre a ciência e a religião: "White's views have shaped lay understanding of Science and religion interactions for more than a century" (Olson, 2004, p. XIV)
} 
cristianismo primitivo teria comprometido o pensamento racional desenvolvido na

Antiguidade:

\begin{abstract}
A tragédia está na natureza seletiva do tráfego que passava pela ponte construída por Agostinho. No pedágio da Cidade de Deus, todos os veículos que traziam os tesouros do saber, beleza e esperança antigos, foram repelidos, pois que toda a virtude pagã "está prostituída pela influência de demônios obscenos e asquerosos... Volte Tales com a água, Anaxímenes com o ar, os estoicos com o fogo, Epicuro com os átomos". [...] O mais bem-vindo foi o desprezo neoplatônico por todos os ramos da ciência. Deles Agostinho 'tirou a convicção, que transmitiu às gerações seguintes de muitos séculos, de o único tipo de conhecimento desejável ser o conhecimento de Deus e da alma, e de não haver proveito nenhum na investigação do reino da natureza.' (Koestler, 1999, p. 55).
\end{abstract}

Mesmo que o texto de Koestler tenha algumas décadas, ainda podemos encontrar essa forma interpretativa presente na produção de historiadores no século XXI. É o caso de Charles P. Freeman, especialista em Grécia e Roma, que publicou, em 2003, The Closing of the Western Mind: The Rise of Faith and the Fall of Reason, cuja tradução livre seria "O fechamento da mente ocidental: A ascensão da fé e a queda da razão". Vejamos um trecho do livro:

É possível encontrar uma combinação de fatores por detrás do 'fechamento da mente ocidental': o ataque à filosofia grega por parte de [o apóstolo] Paulo, a adoção do platonismo por parte dos cristãos e a imposição da ortodoxia por imperadores desesperados por manter a ordem nos seus domínios. A imposição da ortodoxia seguiu de mãos dadas com a sufocação de qualquer forma de pensamento independente. No século $\mathrm{V}$, não só o pensamento racional fora suprimido, como se dera a sua substituição por 'mistério, magia e autoridade"'. (Freemanapud Lindberg, 2012, p. 23).

Outro exemplo contemporâneo deste tipo de representação pode ser encontrado no livro História Moderna, de Paulo Miceli (2018).Ainda que o autor tenha tomado o devido cuidado durante quase todo o livroem não demonstrar qualquer tipo de representação pejorativa da Idade Média,o fechamento de seu quarto capítulo, Entre a religião e a ciência,de tom quase poético, acaba por representar o intelecto dos eclesiásticos do final da Idade Média como "pequenos, atordoados e adormecidos", ou seja, limitados se comparados com as novas ideias trazidas por Galileu, Copérnico e outros.

Na verdade, enquanto a Terra e os planetas se moviam ao redor do Sol, [os homens da Igreja] temerosos de perder seus privilégios, imobilizados - estes, sim - no conforto de seus conventos e palácios, os antigos guardiões das verdades que se desmentiam assistiam, sem compreender, novos homens, novas ideias, novos livros e novos mundos à volta de seus pequenos, atordoados e adormecidos intelectos (Miceli, 2018, p. 92, grifo nosso). 
Poderíamos nos prolongar nos exemplos, tendo em vista a grande quantidade de divulgadores científicos e de historiadores que opõem a religião cristã à emergência da Ciência Moderna, ou, no mínimo, compreendem que a Igreja foi, em alguma medida, prejudicial ao desenvolvimento científico. Entretanto, diante da iminente possibilidade de enfado do leitor, paramos por aqui. A seguir, buscaremos analisar os principais argumentos de Edward Grant no que se refere a sua perspectiva continuísta e, também, à reavaliação dos tensionamentos entre a Igreja e a Ciência no período medieval.

\section{As bases da Ciência Moderna na Idade Média: a proposta continuísta de Edward Grant}

Diferentemente de boa parte da historiografia da ciência hegemônica,Edward Grant, historiador da ciência estadunidense e professor emérito da Universidade de Indiana, sustenta a hipótese de que a Revolução Científica não deve ser entendida de forma descolada do período que a antecedeu. Isso porque este pesquisador, que faz parte de um conjunto maior de historiadores continuístas da ciência medieval ${ }^{36}$, identifica que as bases do pensamento científico dos séculos XVI e XVII foram edificadas na Baixa Idade Média ocidental. Teria sido entre os séculos XII e XV que o pensamento lógico alcançaria elevados patamares entre os intelectuais europeus, criando uma cultura investigativa que teria fomentado as bases do pensamento científico dos séculos de Copérnico, Galileu e Newton. Mais do que apenas influenciar a Ciência Moderna, Grant defende que há uma espécie de causalidade entre o cenário intelectual medieval e a emergência da Revolução Científica:

Poderia [a Revolução Científica] ter ocorrido no século XVII se o nível da ciência na Europa Ocidental tivesse permanecido tal como no século XII [?]. Ou seja, poderia ter havido uma revolução científica no século XVII se nunca se tivesse traduzido para latim inúmeros textos de ciência e de filosofia natural greco-árabe? A resposta parecia óbvia: não, não podia. (Grant, 2002, p. VIII).

Para o autor, dentre uma série de processos ocorridos na Baixa Idade Média em relação à História da Ciência, dois se destacariam: as traduções para o latim dos grandes tratados gregos de filosofia natural que se encontravam tanto na língua grega como na árabe e o nascimento das universidades medievais como centros de pesquisa autônomos, ambos

\footnotetext{
${ }^{36}$ Os historiadores continuístas defendem, de diferentes formas, continuidades entre a ciência medieval e a moderna. Pierre Duhem e Marshall Clagett, por exemplo, identificam como a física galilaica e newtoniana são desdobramentos de reflexões medievais. Já Alistair C. Crombie, outro notório continuísta, defende que as bases do método científico empirista que caracterizaria a Revolução Científica já existiam na Baixa Idade Média (Beltrán, 1995).
} 
acompanhados pela emergência da figura dos teólogos-filósofos naturais - grupo de clérigos que, além da prática da Teologia, dedicavam-se à investigação da natureza (Grant, 2002, p. $200-204)$.

Esses eventos teriam sido fundamentais para legar à Modernidade um cenário apropriado para a emergência da Ciência Moderna. As traduções dos grandes tratados de filosofia da Antiguidade teriam não apenas influenciado a agenda filosófica da Escolástica medieval, mas também, servido de base curricular para as recém-criadas universidades.

A partir do século XII, muitos dos tratados aristotélicos sobre Lógica e filosofia natural passaram a ser traduzidos do grego e do árabe para o latim. É importante sinalizar que o legado teórico de Aristóteles exerceu um papel fundamental na edificação do conhecimento racional não apenas na Idade Média ocidental, mas também na tradição latina da Antiguidade Tardia, na cultura filosófica bizantina e também entre os faylasufs árabes dos séculos IX, X, XI e XII ${ }^{37}$. Além da fundamental importância nas reflexões sobre ética, moral, teologia e metafísica durante a consolidação do pensamento escolástico, os trabalhos do filósofo grego, e de todo corpus peripatético, teriam, também, influenciado o desenvolvimento do pensamento racional e científico.

Thiago de Veneza e Guilherme de Moerbeke são exemplos de tradutores relacionadas à língua grega. O primeiro teria traduzido as obras aristotélicas Física, Sobre a Alma, Parva Naturalia e parte do Metafísica. Já Moerbeke, além de ter feito a primeira tradução latina de muitas das principais obras sobre mecânica de Arquimedes e ter traduzido parte das obras de Aristóteles relacionadas à Biologia, lançou luzs obre importantes trabalhos de João Filopono e Simplício a respeito da teoria do movimento dos corpos.

Em relação às traduções para o latim dos tratados de filosofia natural em língua árabe, pensadores do século XII, tais como Platão de Tivoli, Adelardo de Bath, Roberto de Chester, Michael Scote, com mais notoriedade, Geraldo de Cremona, disponibilizaram ao Ocidente medieval uma série de tratados sobre Medicina, Astronomia, Alquimia,Matemática e Física. Aproveitando a grande circulação de obras em língua árabe no território espanhol, esses pensadores traduziram para o latim não apenas importantes obras aristotélicas, como Física, Sobre o Céu, Da Geração e da Corrupção, Meteorológicos e Analíticos posteriores, como também tratados científicos de consagrados pensadores, tais como Ptolomeu e Averróis.

\footnotetext{
${ }^{37}$ Parte dos pesquisadores, como Karen Armstrong, defendem que o pensamento lógico-racional não apenas se fez presente no Islã medieval como, inclusive, teve direta influência na teologia: "Os faylasufs[...] chegaram à conclusão [que] o racionalismo era a mais avançada forma de religião, pois permitia desenvolver uma noção de Deus superior ao Deus revelado das Escrituras.” (Armstrong, 2008, p. 221)
} 
O outro fenômeno medieval destacado por Grant como fundamental para a edificação do pensamento científico é a emergência das universidades. Tanto a primeira delas, a Universidade de Bolonha, fundada em 1088, quanto Oxford, Paris e uma série de outras que surgiram a partir do século XII, teriam sido fundamentais para o desenvolvimento do pensamento crítico. Segundo Grant, o modus operandi das universidades medievais teria criado uma cultura acadêmica de questionamento que fundamentou o modo de funcionamento das universidades modernas. As lições (lectio) e os debates (disputatio) fariam parte da rotina de seus docentes e discentes por centenas de anos, criando uma robusta cultura investigativa. Além disso, o autor defende que essas instituições teriam sido muito importantes na formação de metodologias voltadas ao desenvolvimento do conhecimento, criando, por exemplo, o método de questiones ${ }^{38}$.

Assim, para Edward Grant, a Baixa Idade Média teve fulcralimportância na construção do pensamento científico moderno, fornecendo-lhe não apenas corpusteórico- por meio de traduções, comentários e tratados - mas também instituições universitárias - corporações cuja finalidade era a produção de conhecimento.Mas, em que medida a Igreja teria influenciado esse processo? Como Edward Grant observa a inter-relação entre o cristianismo e o pensamento racional?

\footnotetext{
${ }^{38}$ As questiones eram uma série de perguntas levantadas a respeito das premissas aristotélicas que motivavam profundas reflexões tanto nos mestres em artes quanto em seus alunos. Eram, na maior parte das vezes, perguntadas e respondidas oralmente. O seu correspondente escrito chamava-se questio. "Em função da sua estrutura, configurada como um debate, a forma de literatura e análise que é a questio tornou-se quase sinônima do conceito de 'método escolástico' medieval." "[...] os escolásticos tendiam a apresentar os seus argumentos num formato bastante estandartizado que permanece notavelmente constante ao longo dos séculos. Em primeiro lugar aparecia o enunciado do problema, começando na maioria dos casos por uma expressão do gênero 'Perguntemo-nos se' ou, simplesmente, 'Se' (utrum, implicando a alternativa sim ou não). Por exemplo, 'Se a Terra é esférica', ou 'Se a Terra se move', ou 'Se é possível que existam vários mundos." Seguiam-se um ou mais - por vezes até cinco ou seis - raciocínios da posição negativa ou afirmativa. Se os argumentos em defesa da posição afirmativa apareciam primeiro, o leitor podia supor que o autor adotaria provavelmente a posição negativa; em contrapartida, se a posição negativa surgisse primeiro, era de se esperar que o autor fosse adotar e defender mais tarde a posição afirmativa. As opiniões iniciais, que acabariam por ser rejeitadas, eram denominadas 'argumentos principais' (rationes principales)" "[...] o autor apresentava sumariamente a opinião oposta, em geral introduzida pelo termo oppositum." O oppositum confinava-se em larga medida à citação de pelo menos uma autoridade na matéria - frequentemente o próprio Aristóteles - que estava em desacordo com a opinião afirmativa inicial." "Após os argumentos principais e opostos, o autor poderia ainda esclarecer e qualificar o seu entendimento da questão ou explicar termos específicos que nela surgissem." Por fim, "Depois de acrescentar tantas qualificações quantas julgasse necessárias, o autor estava pronto a apresentar as suas próprias opiniões, geralmente através de uma ou mais conclusões e, depois, resolvê-las." (Grant, 2002, p. 149151)
} 


\section{A importância do cristianismo para a Ciência Moderna na perspectiva de Edward Grant}

Na condição de um historiador da ciência dedicado ao estudo dos avanços científicos medievais, parte significativa das pesquisas de Grant acaba esbarrando nos mitos e preconceitos que envolvem esse debate. Assim, o autor foi, por vezes, obrigado a realizar uma genealogia dos estereótipos que permeiam o debate sobre o relacionamento entre o cristianismo e a Ciência Moderna. Um exemplo manifesto pode ser encontrado no início daobra Science and Religion, 400 B.C. to A.D. 1550: from Aristotle to Copernicus (2004), na qual podemos identificar a motivação de escrita do autor:

[...] apenas um aspecto dessa hostilidade [hostilidade em relação aos teóricos e teólogos medievais] nos interessará neste volume - os ataques contra o estudo medieval da lógica, da filosofia natural e da teologia direcionados às, aproximadamente, sessenta universidades criadas no período de 1200 a 1500, um ataque que começou no século XVI e continuou até o século XIX (Grant, 2004, p. 5, tradução nossa)

Para Edward Grant, a caracterização estereotipada da Idade Média tem raízesantigas. “O ataque à Escolástica medieval começou na Idade Média com Francesco Petrarca (A.D. 1304 - 1374)" (Grant, 2004, p. 6, tradução nossa), sendo que as críticas se dirigiam aos filósofos seguidores de Aristóteles por, supostamente, estudar a Lógica "por ela mesma" e não aplicar o conhecimento lógicoa outras finalidades. O sentimento anti-escolástico seria cultivado e disseminado por importantes figuras nos séculos seguintes, tais como Lorenzo Valla, Erasmo de Roterdã, Thomas More, Juan Vives e outros pensadores associados à Renascença, que buscaram, de formas distintas, denunciar problemas nas estruturas intelectuais escolásticas.

Alguns protagonistas da chamada Revolução Científica engrossariam o coro das críticas ao período medieval, dedicando maior ênfase à dimensão científica. Galileu, ptolomaico e copernicano, ainda que admirador de Aristóteles, censurou seus seguidores medievais que, supostamente, teriam desenvolvido pouco a herança intelectual peripatética. Em suas críticas ácidas aos escolásticos, Galileu teria dito que os medievais eram mero reprodutores das ideias de Aristóteles e que nada teriam avançado no que se refere aos estudos sobre a filosofia natural,dando início a um modelo de críticas que se tornaria comum entre os filósofos naturais da Modernidade: "Galileu moldou os julgamentos sobre o escolasticismo medieval pelos séculos que se seguiram" (Grant, 2004, p. 11, tradução nossa). Assim, como 
desdobramento da representação estereotipada "Idade das Trevas", a ciência e o pensamento científico produzido no período medieval foram relegados a um segundo plano.

Tal forma de representação teria permanecido nos séculos seguintes, contribuindo para a construção de uma imagem depreciativa dos medievais até o século XX. Ainda que pensadores de peso tenham dedicado importantes reflexões voltadas à valorização do pensamento científico-racional da Baixa Idade Média- tais como Pierre Duhem, Lynn Thorndike, Alistair Crombie e Marshall Clagett -, grande parte dos historiadores da ciência e dos divulgadores científicos continuou, e, de certa forma continua, negligenciando a importância do período no que se refere à construção do conhecimento filosófico-natural, caso de Singer: "muitas tentativas foram feitas para reabilitar as conquistas intelectuais da Idade Média. No que se refere à ciência, elas foram malsucedidas. Não existe razão para reverter a decisão de que neste domínio o período é de degradação intelectual.” (Singer, 1941, p. 161 apud. Grant, 2004, p. 11, tradução nossa).

Fato é que Grant se opõe a esses tipos de representação e, mais do que destacar a fundamental importância da Baixa Idade Média na edificação da Ciência Moderna, entende que a Igreja teve um papel basilar nesse processo. Mas, antes de abordarmos a forma com a qual Edward Grant caracteriza o relacionamento entre Igreja e o surgimento da Ciência Moderna, faz-se necessário um esclarecimento. Como visto, este autor se insere em um contexto mais amplo de historiadores da ciência medieval que analisam, de diferentes maneiras, continuidades entre a ciência do período medieval e moderno e a inter-relação entre o desenvolvimento do espírito científico e a Igreja Católica na Baixa Idade Média. Assim, trabalham com períodos anteriores à Reforma Protestante. Isso quer dizer que quando mencionamos “cristianismo" estamos nos referindo à Igreja Católica Apostólica Romana que atuou na Europa Ocidental na Baixa Idade Média ${ }^{39}$.

Para Grant, o relacionamento entre a religião cristã e o pensamento racional teria começado cedo: longe da concepção de que a ascensão do cristianismo primitivo significou a derrocada do pensamento lógico-filosófico, como nos apontou anteriormente Koestler (1999), o historiador norte-americano defende que os cristãos dos primeiros séculos acabaram por incorporar uma série de elementos da cultura pagã em sua doutrina, entre eles, o pensamento racional. Isso porque, em meio a uma razoável quantidade de religiões que emergiram no

\footnotetext{
${ }^{39}$ Há outras correntes historiográficas e sociológicas que reconhecem o nascimento da Ciência Moderna a partir de outra ala do cristianismo: o Protestantismo. Robert K. Merton, por exemplo, defende a hipótese de que o surgimento da ciência, como prática de conhecimento legítimo e independente, está diretamente ligado à construção, por parte de correntes da Igreja Protestante, de um código de ética que permitiu uma nova forma de ver o mundo. Esse código, pensado a partir de uma notória derivação do modelo sociológico weberiano, recebeu o nome de "éthos puritano" (Cf. Merton, 1938).
} 
Império Romano, entre os séculos I a.C. e os três seguintes, o cristianismo, religião de matriz abraãmica, só veio a consolidar-se hegemonicamente no século IV d.C., nos governos de Constantino e de Teodósio. Segundo Grant, o fato de o cristianismo ter demorado séculos para tornar-se hegemônico forçou a doutrina a ser mais maleável e a incorporar uma série de elementos teóricos e litúrgicos de origem pagã não previstos originalmente.

Isso fica evidente se analisarmos a postura teórica dos pais gregos e latinos da Igreja, como Justino, Clemente de Alexandria, Orígenes, Gaius Marius Victorinus e Santo Agostinho, que teriam ressaltado a importância da filosofia natural e da Lógica como formas de se chegar a uma maior compreensão das Escrituras. Longe de defender o fim do pensamento racional, os pais da Igreja fizeram um uso instrumental das reflexões lógico-filosóficas herdadas das tradições grega e romana para desenvolver assuntos pertinentes à seara teológica. Isso fica claroao observarmos, como exemplo, o uso queAgostinho fez do método da lógica silogística aristotélica para comprovar a possibilidade da ressureição: "Se não há ressurreição dos mortos então Cristo não ressuscitou. Mas Cristo ressuscitou, logo, existe a ressureição dos mortos" (Agostinho, 1996, 1955apud Grant, 2004, p. 114) ${ }^{40}$.

Segundo Grant, a morosidade no processo de consolidação da doutrina como a profissão de fé oficial do Império e a consequente incorporação de elementos das culturas pagãs teria feito do cristianismo uma religião mais maleável em relação às diferenças culturais. É por esse motivo que os cristãos ocidentais quase não ofereceram resistência ao reavivamento dos estudos sobre Lógica no século XII. O pensamento racional e o desenvolvimento da filosofia natural greco-romana já haviam feito parte da agenda teológica dos pais da Igreja.

Essa característica deve ser vista em contraste com a rápida e incisiva expansão do islamismo que, em apenas 100 anos após a morte do profeta Muhammad (632), conquistou todo o norte da África e boa parte do Oriente Médio, de Gibraltar à Pérsia. A política de expansão territorial, associada à conquista e conversão dos povos nômades, teria feito do islamismo uma religião mais fechada às influências culturais de outras civilizações.Esse seria, para Grant, um primeiro possível motivo da estagnação da rica cultura científica árabe a partir do século XIII: "De fato, as ciências estrangeiras desempenhavam um papel bastante marginal nas madrasas, que formavam o núcleo da educação superior islâmica." (Grant, 2004, p. 243, tradução nossa).

\footnotetext{
${ }^{40}$ AGOSTINHO. Saint Agostine, Teaching Christianity (De Doctrina Christiana). In ROTELLE, J. E. (ed.) The Works of Saint Agustone. A Translation for the 21st Century. Vol. 11. Hyde Park, NY: New City Press, 1996
} 
Outra particularidade que, na visão do autor, foi fundamental para que a filosofia natural prosperasse na Europa Ocidental foi a separação entre a Igreja e o Estado -“a Cesar o que é de Cesar, e a Deus o que é de Deus." (Mateus 22:21). Ainda que essa separação tenha sido, por vezes, pouco evidente durante certos períodos da Alta Idade Média, proporcionou na Baixa condições para que as universidades criassem certa autonomia, afastando, em alguma medida,essas instituições das disputas de poder que opunham Igreja e Estado.

Dentro da argumentação de Grant, essa separação foi fundamental pois impediu que o avanço de tendências conservadoras cristãs influenciasse o desenvolvimento da filosofia natural ocidental. Para o autor, seriam três as condições que garantiriam a não ingerência do conservadorismo religioso no desenvolvimento do pensamento filosófico natural: (1) a filosofia natural ser considerada uma disciplina independente de estudos; (2) O Estado dar suporte e proteger esse campo de conhecimento; (3) As autoridades religiosas olharem com bons olhos para essa disciplina (Grant, 2004, p. 242).E é a partir dessa constatação que Grant identifica um segundo possível motivo para justificar a estagnação da ciência árabe: as tensões entre os filósofos naturais e os teólogos teriam feito com que a sociedade islâmica, de natureza teocrática, enfraquecesse os investimentos nas madrasas e coibisse qualquer forma de conhecimento que contrariasse a verdade revelada do Corão.

Como vimos, durante a Antiguidade Tardia e a Alta Idade Média, o estudo da lógica aristotélica teria permanecido nos centros de circulação intelectual grego e latino.Figuras como Santo Ambrosio, Santo Agostinho, Boécio, Gregório o Grande (Papa Gregório) e João Filopono seriam exemplos da permanência do pensamento racional e da filosofia natural ligados, principalmente, aos circuitos intelectuais teológicos. Entretanto, mesmo observando casos isolados de desenvolvimento intelectual, tal como o Renascimento Carolíngio, Grant identifica que o período entre os séculos VII e XI foi, na Europa Ocidental, marcado pelo esmorecimento do pensamento técnico e científico. A descentralização político-administrativa e a diminuição das áreas urbanas promovidas pela ascensão do regime feudal são possíveis explicações para esta estagnação.

O hiato seria quebrado no século XII, com a retomada dos trabalhos de Aristóteles sobre Lógica e, algumas décadas depois, sobre filosofia natural.Desde o século XI, a Europa Ocidental começava a experenciar um processo de aumento populacional e comercial, o que impactou o desenvolvimento educacional e científico. Em 1079 o Papa Gregório VII estabelece diretrizes para a criação de escolas nos mosteiros para a educação e treinamento dos padres. Neste mesmo século, monastérios em Paris, Orleans, Toledo, Reims, Chartres, Colônia e outras cidades já contariam com centros educacionais. Gerbert de Aurillac (946 a 
1003), ou Papa Sylvester II, foi uma figura icônica desse processo pois, além de ter lecionado as sete artes liberais ${ }^{41}$ em Reims na França, foi o responsável pelo retorno dos estudos lógicos de Boécio.

A própria universidade medieval deve ser encarada como um desdobramento das escolas episcopais medievais: "a universidade [...] teve uma história que começa com as escolas catedráticas, uma classe de escolas patrocinadas por catedrais que floresceram durante os séculos XI e XII." (Grant, 2004, p. 170, tradução nossa). Estudantes e professores vinham de toda parte da Europa para esses centros de formação. Como a maior parte dessa comunidade escolar vinha de territórios estrangeiros, professores e alunos não gozavam dos direitos civis das cidades que sediavam os centros de ensino. Assim, para obter respaldo institucional, acabaram por formar corporações "ou universitas, assim como também aconteceu com muitas guildas de artesãos e mercadores." (Grant, 2004, p. 171, tradução nossa).

Assim, a institucionalização das escolas em universitas fez com que adquirissem autonomia jurídico-financeira. Os próprios membros da comunidade poderiam organizar-se administrativamente, escolhendo, inclusive, seus representantes, aptos a representar as universidades frente às leis, ao Estado e à Igreja. Essa autonomia fez com que a universidade medieval se desenvolvesse:

A estrutura corporativa da universidade medieval proporcionou uma substancial estabilidade e, assim, permitiu que o ensino da filosofia natural se desenvolvesse como a base de toda a aprendizagem universitária nas quatro faculdades que compreendiam uma grande universidade, a saber: artes, teologia, medicina e direito (Grant, 2004, p. 172, tradução nossa).

As universidades eram divididas em quatro áreas de conhecimento: Artes, Teologia, Medicina e Direito. Para se formar nestas últimas três especializações, o estudante deveria, antes de tudo, formar-se Mestre em Artes, curso que tinha como currículo os principais tratados aristotélicos sobre filosofia natural. Por isso os futuros teólogos, físicos (médicos) e juristas seriam familiarizados com a Lógica e com a filosofia natural ${ }^{42}$.

\footnotetext{
${ }^{41}$ Trivium - Gramática, Retórica e Dialética - e Quadrivium - Geometria, Aritmética, Astronomia e Música

${ }^{42}$ Para Grant, a filosofia natural deve ser encarada como "a mãe das ciências". Isso porque, embora haja uma controvérsia histórica sobre a possibilidade de recair em anacronismo ao considerar a prática filosófica natural medieval como "ciência", é inegável que boa parte da agenda dos filósofos naturais medievaisse desdobrouno que hoje chamamos de campo científico - como, por exemplo, o estudo do deslocamento dos corpos -, assunto complexo e multifacetado, não será trabalhado neste artigo. Assim, adotamos, neste texto, a diretriz analítica de Grant, menos preocupada em investigar os limites do uso do conceito "ciência" e mais interessadana análise dos contributos científicos medievais.
} 
Tanto faz quais forem as suas carreiras, se como professor em artes, se como praticantes ou professores de teologia, leis, ou medicina, ou como clérigo na corte real ou na municipalidade - todos os estudantes adquiririam um conhecimento básico de lógica e filosofia natural como útil, se não indispensável, nas altas disciplinas de teologia, leis e medicina.(Grant, 2004, p. 172)

A necessária titulação em Artes fez com que parte significativa dos teólogos tivesse de aprender filosofia natural antes de iniciarem os estudos em Teologia. Isso, segundo Grant, fez com que surgisse a figura do teólogo-filósofo natural, um religioso que, para além dos campos de estudos sacerdotais, voltava sua atenção à investigação do funcionamento da natureza. Muito além do uso da Lógica para fins de leitura das Escrituras ${ }^{43}$, figuras como Adelardo de Bath e Guilherme de Conches, fazendo uso das recém traduzidas obras clássicas da filosofia natural, passaram a alargar o escopo investigativo dos teólogos do século XII. O primeiro, após viagem para o Oriente Médio, divulgou a Matemática e a Geometria de Os Elementos de Euclides na Europa Ocidental. Já Conches escreveu diversos trabalhos voltados aos estudos naturais, como De philosophia mundi, tratado dedicado ao estudo da composição dos corpos que utiliza e recomenda o método racional como forma verdadeiramente legitima de investigação. A natureza começava a ser estudada para além dos limites da Teologia.

O surgimento da figura do teólogo-filósofo natural foi fundamental para o desenvolvimento da investigação científica nos próximos séculos. Ainda que parcela dos teólogos tenham imposto limites ao uso da razão para análises teológicas - tais como Pedro Damião, no século XI, e Bernardo de Claraval, no XII-, a prática se consolidou no cenário intelectual da Baixa Idade Média e teólogos que também eram filósofos naturais - a exemplo de Thomas de Aquino, Jean Buridan,Thomas Bradwardine, Nicole de Oresme, Alberto da Saxônia e muitos outros - alargaram os limites da compreensão dos ocidentais sobre Matemática, Geometria, Física, Geografia, Cosmologia, Astronomia, Astrologia, Alquimia e muitos outros conhecimentos.

A Igreja, portanto, na perspectiva de Grant, não teria frustrado o desenvolvimento do pensamento racional, ao contrário, teria ajudado a desenvolvê-lo. Mesmo nas situações de conflito - como quando a instituição religiosa impôs aos teólogos naturais do século XIII uma

\footnotetext{
${ }^{43}$ Durante os séculos XI e XII, houve um movimento teológico de revalorização da Lógicacomo metodologia para a análise de questões teológicas. Embora alguns pensadores desaprovassem essa prática, como São Pedro Damião, o uso da Lógica passou a fazer parte do currículo de formação dos jovens clérigos. Pedro Abelardo, João de Salisbury e Pedro Lombardo são exemplos da primeira geração de teólogos da Baixa Idade Média que voltaram a utilizar, de maneira instrumental, a lógica aristotélica na resolução de problemas teológicos. Este último, inclusive, "escreveu um tratado chamado Os Quatro Livros das Sentenças, que se tornou o livro básico em todas as escolas de Teologia no Ocidente latino até o século XVII." (Grant, 2004, p. 159, tradução nossa), tratado que teria grande influência em Tomás de Aquino.
} 
série de juramentos que recomendavam aos filósofos sempre tomar o lado da Igreja quando alguma questão natural colocava em conflito a razão e os dogmas cristãos, ou mesmo a Condenação de 1277, famosa Condenação de Paris em que o Bispo Tempier condenou 219 proposições filosóficas baseadas em concepções aristotélicas que divergiam das orientações bíblicas -, não teria atrapalhado o desenvolvimento do pensamento científico medieval,pelo contrário, Grant afirma que a forma com a qual os filósofos naturais contornaram limitações teria elevado ainda mais a contribuição medieval para o desenvolvimento da disciplina.

$\mathrm{Na}$ perspectiva do autor, as tentativas de coibir o uso da filosofia natural acabaram, muitas vezes, atingindo o objetivo oposto, alargando, ainda mais, os horizontes da disciplina. Um exemplo, dentre muitos, envolve o caso do teólogo-filósofo natural Jean Buridan. A Condenação de $1277^{44}$ teria imposto restrições às concepções aristotélicas que divergiam de dogmas cristãos, e, entre muitas ${ }^{45}$,"Que Deus não poderia mover os céus [ou o Mundo] com um movimento retilíneo; e a razão é que isso geraria vácuo.”46 (Grant, 2004, p. 183, tradução nossa). Essa condenação se refere a uma antiga questão: segundo a teoria do movimento de Aristóteles, a existência do vácuo seria impossível. Isso porque, grosso modo, o filósofo grego defendia que a sustentação do movimento violento ${ }^{47}$ se daria pelo impulso gerado pelo próprio ambiente. Uma pedra atirada para frente, por exemplo, teria como veículo propulsor o próprio ar que, a cada instante, seria expulso de sua dianteira e, automaticamente, iria exercer função de impulso em sua parte traseira. Para Aristóteles, o movimento no vácuo, ou ausência total de meio, teria de ser instantâneo, independentemente da distância a ser percorrida,o que, em sua concepção, seria um absurdo. Isso levou o filósofo a rechaçar a existência de ambientes com total ausência de matéria.

Segundo a Condenação, se fosse de seu desejo, Deus poderia criar o vácuo. Essa recomendação obrigou os teólogos-filósofos naturais a desenvolverem teorias do movimento

\footnotetext{
${ }^{44}$ Para se ter uma ideia da polarização dos debates que ocorriam na época, citamos quatro das condenações de Tampier: "152. Que as discussões teológicas são baseadas em fábulas; 153. Que nada pode ser melhor compreendido por se conhecer teologia; 154. Que apenas homens sentatos são filósofos; 155. A Revelação Cristã é um obstáculo para o conhecimento" (Grant, 2004, p. 182, tradução nossa).

${ }^{45}$ Como, por exemplo, as ideias de Aristóteles sobre aimpossibilidade de existência de outros mundos, que contrariava o poder absoluto de Deus, ou mesmo a concepção de eternidade do universo, que colocava em xeque a narrativa da Criação.

${ }^{46}$ Artigo 49.

${ }^{47}$ Movimento violento é, para Aristóteles, aquele que contraria o movimento natural. Os corpos, compostos de distintas proporções dos quatro elementos - terra, água, fogo e ar - tenderiam a ocupar seu lugar natural na cosmologia aristotélica, isto é, corpos com mais terra, o elemento mais "pesado", deveriam ficar mais próximos do centro do universo, o lugar natural da terra. Já corpos que teriam o elemento água em maior proporção, tenderiam a manter-se na camada de água, entre a terra e o ar. Essa mesma lógica serviria para as camadas de ar e fogo e isso regularia o movimento natural de todos os corpos do universo. Um exemplo é a pedra que, naturalmente, fica próxima do chão, lugar natural de elementos que seriam predominantemente compostos pelo elemento terra. Quando pegamos uma pedra e jogamos para o alto, nós a estamos obrigando a realizar um movimento não-natural, ou melhor, violento.
} 
que transcendessem as limitações da teoria aristotélica. E é nesse cenário que Jean Buridan se insere. Fazendo uso de reflexões de outros importantes filósofos naturais, como João Filopono e Averróis, Buridan passa a defender que a causa de um projétil manter um movimento violento não está ligada ao impulso do ambiente, mas sim, a uma "energia" que passa do motor inicial do movimento para o projétil, ou melhor, oimpetus. Assim, caso Deus criasse o vácuo, um projétil poderia atravessar esse meio em velocidade constante, já que o que moveria o objeto não seria o meio mas a força incorpórea recebida do motor inicial. A pedra atirada por alguém não manteria sua trajetória devido ao impulso do ar, mas sim, por conta da transferência de uma porção de "energia", de impetus, do braço do sujeito para a pedra. A partir dessa conclusão, Buridan avança consideravelmente em relação à teoria aristotélica do movimento e adianta parte das considerações físicas de Galileu e Newton. Esse é um dentre muitos exemplos de avanços que os teólogos-filósofos naturais medievais promoveram para além do legado peripatético.

O que é surpreendente na Idade Média é o fato de que os teólogos, ou mais apropriadamente teólogos-filósofos naturais, bem como filósofos naturais entre os mestres das artes nas universidades, empregaram uma abordagem questionadora em relação a uma ampla gama de problemas envolvendo a natureza, o sobrenatural e condições hipotéticas e imaginárias. Estavam tanto interessados no modo como as coisas poderiam ter sido se Deus fizesse o mundo de forma diferente [...] como nos fenômenos no mundo real. Esse espírito indagador foi um grande desenvolvimento no mundo ocidental durante a Idade Média. [...] $\mathrm{O}$ que talvez seja mais surpreendente neste novo espírito [científico] é que foi dominado por teólogos que empregaram as habilidades analíticas que adquiriram nas universidades para lidar com questões e problemas tanto na filosofia natural quanto na teologia. De fato, eles fizeram da teologia um grande repositório de técnicas analíticas compostas de filosofia natural, lógica e matemática. (Grant, 2004, p. 224, tradução nossa).

Assim, longe de ter sido um período de estagnação intelectual, a Baixa Idade Média teria fornecido as bases para o surgimento do pensamento científico desenvolvido nos séculos XVI e XVII. Então, diferentemente das representações historiográficas nas quais a Igreja é retratada como obstáculo ao desenvolvimento científico, Edward Grant sustenta que o cristianismo teve fundamental importância nesse processo, não apenas influenciando a edificação de instituições superiores de ensino, mas também, através de seus teólogos que se dedicavam aos estudos do mundo natural. 


\section{Bibliografia}

ARMSTRONG, K. Uma história de Deus: quatro milênios de busca do judaísmo, cristianismo e islamismo. São Paulo: Companhia das Letras, 2008

BELTRÁN, A. Revolución Científica, Renacimiento e Historia de la Ciencia. Madrid: Siglo XXI de España Editores S. A., 1995.

FRANCO JR, H. A Idade Média, Nascimento do Ocidente. São Paulo: Brasiliense, 2006

GOULD, S. J. Pilares do Tempo: Ciência e Religião na Plenitude da Vida. Rio de Janeiro: Editora Rocco LTDA., 2002.

GRANT, E. Os fundamentos da ciência moderna na Idade Média. Porto: Porto Ed., 2002.

GRANT, E. Science andReligion, 400 B. C. to A. D. 1550: fromAristotletoCopernicus. Westport: Greenwood Press, 2004

GURTNER, C. Podcast II - Leonardo da Vinci. Escriba Café: A história, o homem, seu mundo e o universo. 21 de dezembro de 2014

GURTNER, C. Podcast XV - A Reforma. Escriba Café: A história, o homem, seu mundo e o universo. 1 de maio de 2017

KOYRÉ, A. Do Mundo Fechado ao Universo Infinito. Rio de Janeiro: Editora ForenseUniversitária LTDA, 1986.

KUHN, T. S. A Estrutura das Revoluções Científicas. São Paulo: Perspectiva, 2013.

LE GOFF, J. A civilização do Ocidente medieval. Petrópolis: Vozes, 2016

LINDBERG, D. C. A ascensão do cristianismo foi responsável pela morte da ciência antiga In NUMBERS, R. L. (org.). Galileu na Prisão e outros mitos sobre ciência e religião. Lisboa: Gradiva Publicações, 2012, p. 23 - 34.

KOESTLER, A. O Homem e o Universo: Como a Concepção de Universo se Modificou, Através dos Tempos. São Paulo: IBRASA Instituição Brasileira de Difusão Cultural LTDA, 1999.

MAGALHÃES, G. Ciência e Conflito: Ensaios sobre História e Epistemologia de Ciências e Técnicas. $1^{\text {a }}$ edição. São Paulo: Book Express Editora, 2015.

MERTON, Robert K. Science, technology and society in Seventeenth-Century England. Osiris, Vol. 4. 1938, p. $360-632$

MICELI, P. História Moderna. São Paulo: Contexto, 2018.

MLODINOW, L. O Andar do Bêbado. Rio de Janeiro: Jorge Zahar Editor Ltda., 2009.

SHANK, H. M. A igreja medieval impediu o desenvolvimento da ciência InNUMBERS, R. L. (org.). Galileu na Prisão e outros mitos sobre ciência e religião. Lisboa: Gradiva Publicações, 2012, p. 35-43.

OLSON, R. Series Foreword In GRANT, E. Science andReligion, 400 B. C. to A. D. 1550: fromAristotletoCopernicus.Westport: Greenwood Press,2004

SHANK, H. M. A igreja medieval impediu o desenvolvimento da ciência InNUMBERS, R. L. (org.). Galileu na Prisão e outros mitos sobre ciência e religião. Lisboa: Gradiva Publicações, 2012, p. 35-43. 